\title{
EXTERNAL DYNAMICS OF DEMOCRATIZATION
}

AND THE ARAB SPRING:

\section{IS IT THE REGION'S SISYPHEAN CURSE?}

\author{
By
}

GHINA A. HARB

\begin{abstract}
A thesis
Submitted in partial fulfillment of the requirements for the degree of Master of Arts in International Affairs
\end{abstract}




\section{Thesis Proposal Form}

Name of Student:

Ghina A. Harb

I.D.\# 200702226

Program / Department:

On 11/12/12:

International Affairs/Social Sciences

has presented a Thesis proposal entitled:

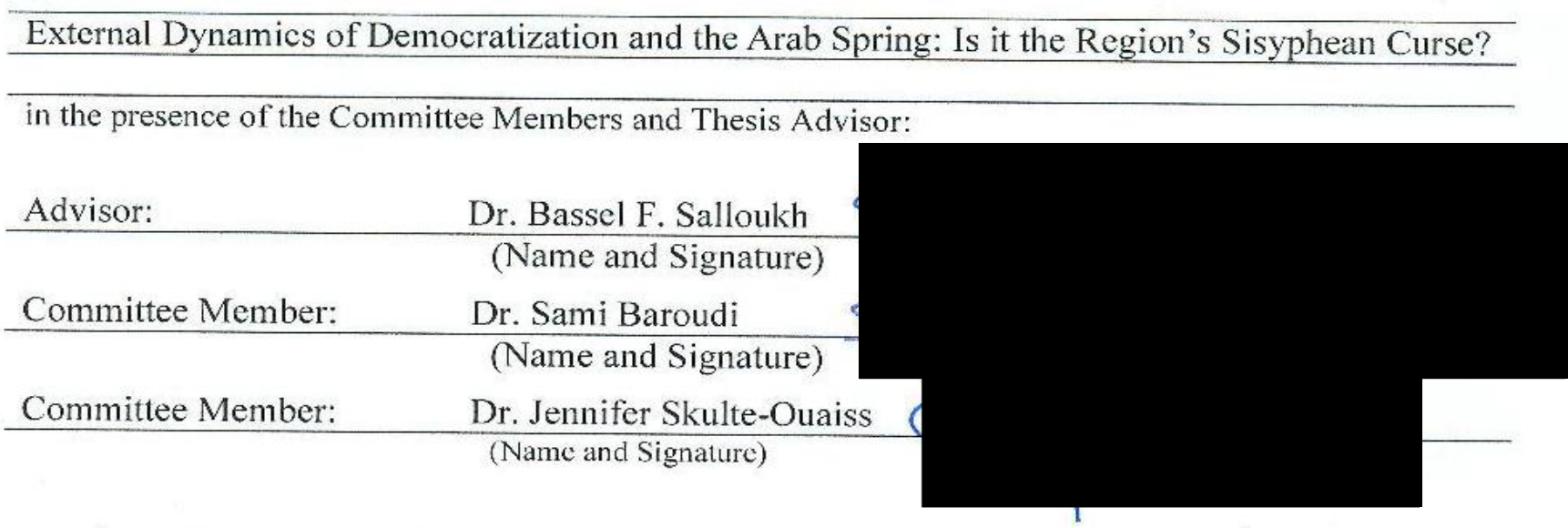

Comments / Remarks / Conditions to Proposal Approval:

Approved

Date: 17/01/2013 Acknowledged by

(Dean, School of Arts and Sciences)

ce: Department Chair

School Dean

Student

Thesis $\Lambda$ dvisor 
DLAU

ح

Lebanese American University
Lebanese American University

School of Arts and Sciences - Beirut Campus

Thesis Defense Result Form
Name of Student:

Program / Department:

Date of thesis defense:

Thesis title:
Ghina A. Harb International Affairs/Social Sciences 29 May 2013

External Dynamics of Democratization and the Arab Spring: Is it the Region's Sisyphean Curse?

I.D.: 200702226

Result of Thesis defense:

Thesis was successfully defended. Passing grade is granted

Q Thesis is approved pending corrections. Passing grade to be granted upon review and approval by thesis Advisor

$\square \quad$ Thesis is not approved. Grade NP is recorded

Committee Members:

Advisor:

Dr. Bassel F. Salloukh (Name and Signature)

Committee Member:

Dr. Sami Baroudi

(Name and Signature)

Committee Member:

Dr. Jennifer Skulte-Ouais

(Name and Signature) 
DLAU

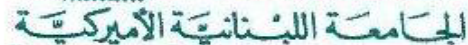

Lebanese American University
Lebanese American University School of Arts and Sciences - Beirut Campus

Thesis Approval Form

Student Name:

Ghina A. Harb

I.D. \#: 200702226

Thesis Title :

External Dynamics of Democratization and the Arab Spring: Is it the Region's Sisyphean Curse?

Program / Department: International Affairs/Social Sciences

School:

Arts \& Sciences

Approved by:

Thesis Advisor:

Dr. Bassel F. Salloukh

Committee Member:

Dr. Sami Baroudi

Committee Member:

Dr, Jennifer Skulte-Ouaiss

Date:

$$
7 \text { Jume } 2013
$$

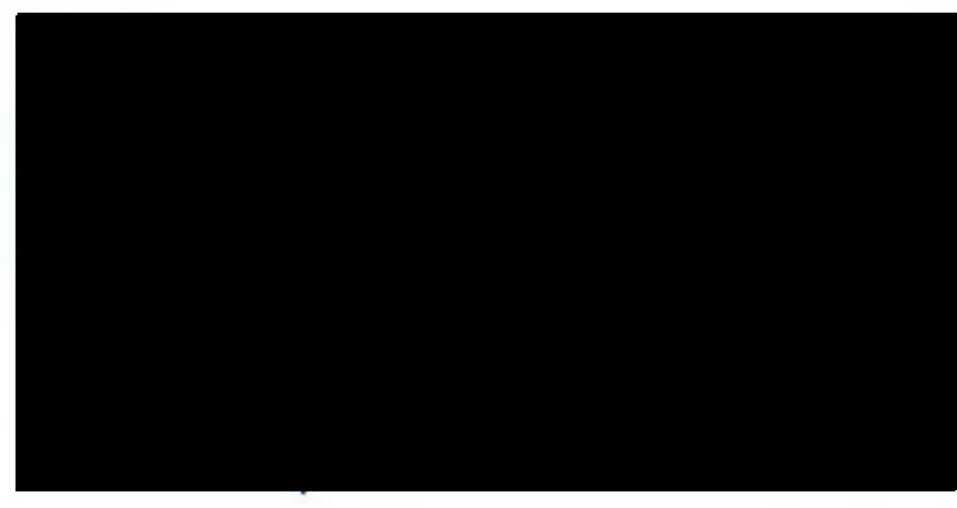




\title{
THESIS COPYRIGHT RELEASE FORM
}

\section{LEBANESE AMERICAN UNIVERSITY NON-EXCLUSIVE DISTRIBUTION}

\begin{abstract}
LICENSE
By signing and submitting this license, I, Ghina Harb, grant to the Lebanese American University (LAU) the non-exclusive right to reproduce, translate (as defined below), and/or distribute my submission (including the abstract) worldwide in print and electronic format and in any medium, including but not limited to audio or video. I agree that LAU may, without changing the content, translate the submission to any medium or format for the purpose of preservation. I also agree that LAU may keep more than one copy of this submission for purposes of security, backup and preservation. I represent that the submission is my original work, and that I have the right to grant the rights contained in this license. I also represent that my submission does not, to the best of your knowledge, infringe upon anyone's copyright. If the submission contains material for which you do not hold copyright, I represent that I have obtained the unrestricted permission of the copyright owner to grant LAU the rights required by this license, and that such third-party owned material is clearly identified and acknowledged within the text or content of the submission. IF THE SUBMISSION IS BASED UPON WORK THAT HAS BEEN SPONSORED OR SUPPORTED BY AN AGENCY OR ORGANIZATION OTHER THAN LAU, I REPRESENT THAT I HAVE FULFILLED ANY RIGHT OF REVIEW OR OTHER OBLIGATIONS REQUIRED BY SUCH CONTRACT OR AGREEMENT. LAU will clearly identify my name as the author or owner of the submission, and will not make any alteration, other than as allowed by this license, to my submission.
\end{abstract}

Name: Ghina Harb

Signature

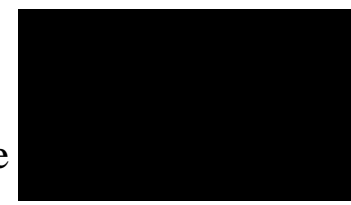

Date: June 7, 2013 


\section{PLAGIARISM POLICY COMPLIANCE STATEMENT}

I certify that I have read and understood LAU's Plagiarism Policy. I understand that failure to comply with this policy can lead to academic and disciplinary actions against me.

This work is substantially my own, and to the extent that any part of this work is not my own I have indicated that by acknowledging its sources.

Name: Ghina Harb

Signature:

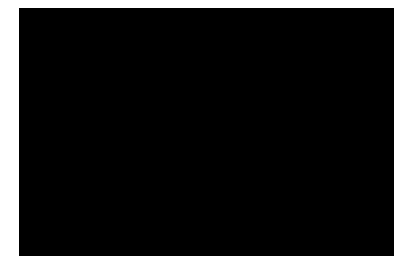

Date: June 7, 2013 


\section{ACKNOWLEDGMENTS}

First and foremost, I want to acknowledge the support and guidance of Professor Bassel Salloukh. His words of encouragement and motivation allowed me to produce a kind of work that I will be proud of forever. Learning and working with him for the past six years had an incredible influence on my personal and academic development. Simply, thank you.

Part of the joy of writing acknowledgments is to look back and think of the people, who, without them, this thesis could not have been possible. Therefore, I want to share my deepest gratitude and thanks to the prominent Lebanese Businessman, Mr. Said Khalaf. Mr. Khalaf, thank you for believing in me and honoring me with the prestigious Lebanese American University merit scholarship of 'Nadim Said Khalaf Scholarship Grant'. Also, I want to thank Ms. Lana Abou Teen, Associate Director of Development at LAU, for her continuous coordination, support, and follow-up.

My tremendous and deep thanks to the Committee members of this thesis, namely, Dr. Sami Baroudi and Dr. Jennifer Skulte-Ouaiss, who, provided me with constructive feedback and kindly agreed to be part of the Committee.

Additionally, I want to express my heartfelt gratitude for my beloved university, and for the Social Science Department, namely, Dr. Huda Abdo, Dr. Imad Salamey, Dr. Shafik Al Masri, and Dr. Ray Jureidini, who believed in me and supported me at all times. Also, I want to thank Dr. Tarek Na'was and Mr. Elie Samia for their continuous encouraging words.

I want to thank my parents and siblings for their unconditional love, which always carries me through. My family and friends have supported me at every endeavor so thank you for being there for me whenever I lose my way around.

Finally, I thank God for his blessing and guidance. 
To honor the memory of Nadim Said Khalaf 


\title{
External Dynamics of Democratization and the Arab Spring
}

\author{
Is it the Region's Sisyphean Curse?
}

\author{
Ghina A. Harb
}

\begin{abstract}
The Arab uprisings have unleashed a wave of authoritarian regime breakdowns in a number of Arab states. Students of Arab politics are consequently examining how the Arab world fits with existing democratic transition paradigms. The main causal variables used in these paradigms pertain to domestic dynamics, however. Yet postauthoritarian regime breakdown dynamics in the Arab world underscore the role of external variables in subsequent democratic transitions. Taking Libya and Bahrain as case studies, this thesis unpacks the role of these external variables. It takes external dynamics as the independent variable and, concomitantly, regime breakdown or maintenance as the dependent variable. A number of indicators are operationalized in a comparative examination of the two cases. The thesis argues that external dynamics are a double-edged sword: they play a determining role in Arab Spring uprisings, either in the direction of authoritarian regime breakdown or persistence.
\end{abstract}

Keywords: Arab Spring, Authoritarianism, Democratic transitions, NATO, Uprising 


\section{TABLE OF CONTENTS}

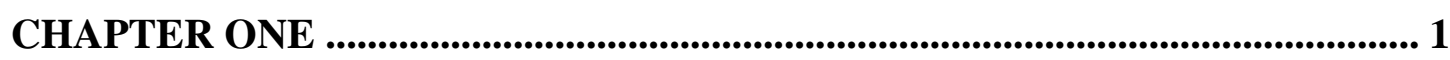

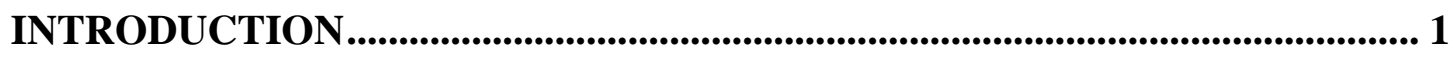

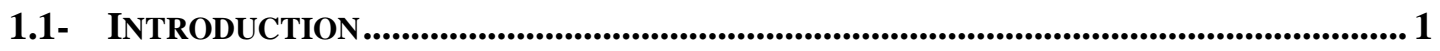

1.2- RESEARCH QUESTION ........................................................................................................ 4

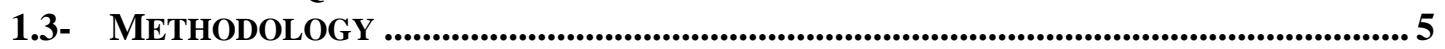

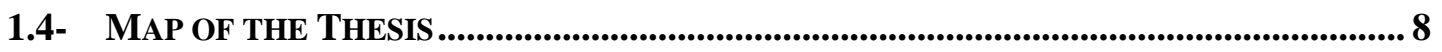

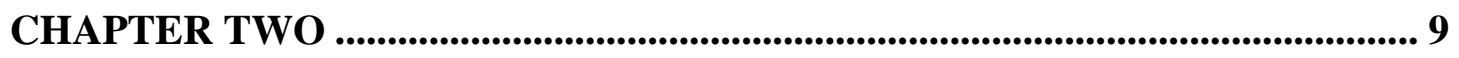

RECONSIDERING AN OVERLOOKED TRANSITION PARADIGM............. 9

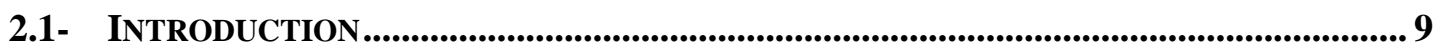

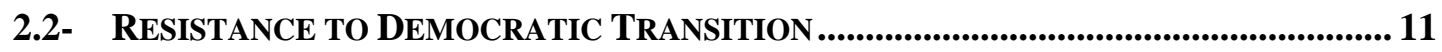

2.3- TRANSITION PARADIGMS IN THE STUDY OF DEMOCRATIZATION ............................ 15

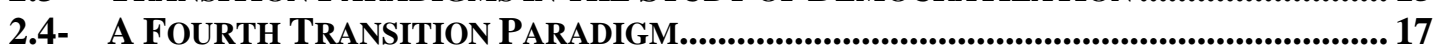

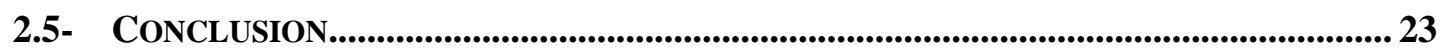

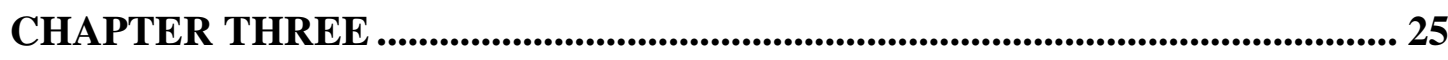

FROM QADDAFI'S IDIOSYNCRATIC CALCULATIONS TO NATO'S AIR-

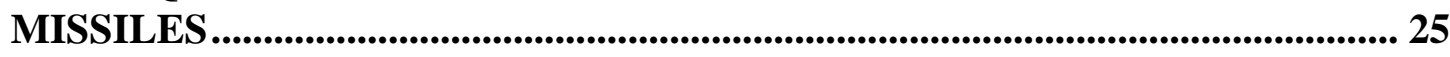

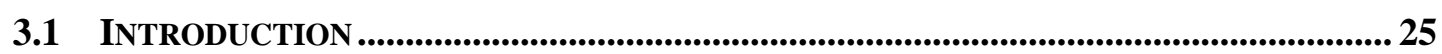

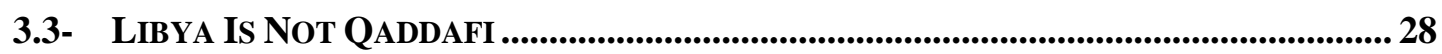

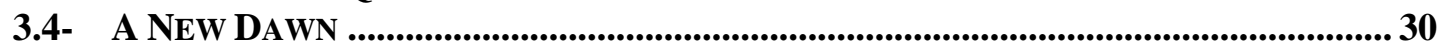

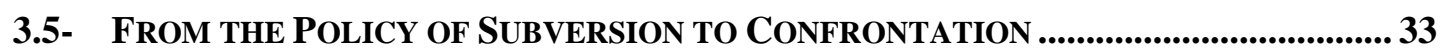

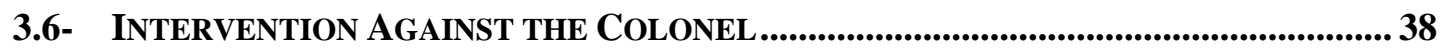

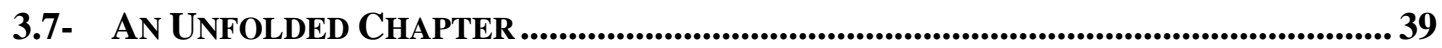

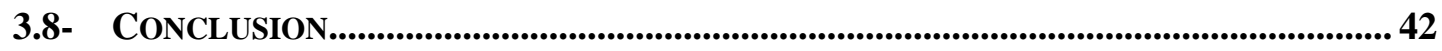

CHAPTER FOUR .............................................................................................. 44

FROM A SHORT LIVED UPRISING TO AN UNFINISHED REVOLUTION 44

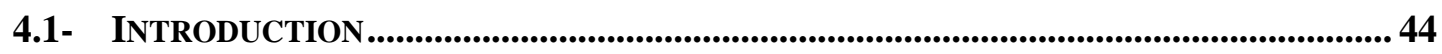

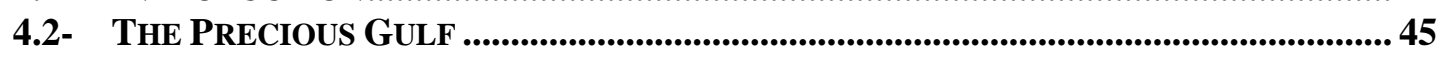

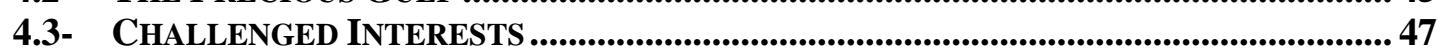

4.4- THE NEW MANIFESTATION ........................................................................................................ 51

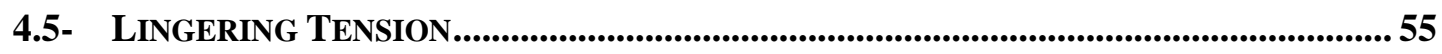

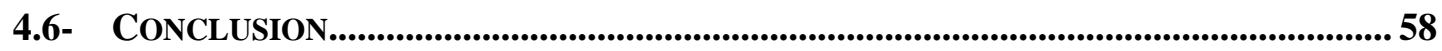

CHAPTER FIVE..........................................................................................................................6 60

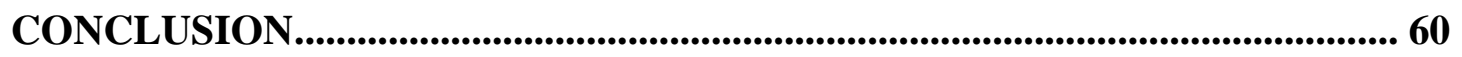

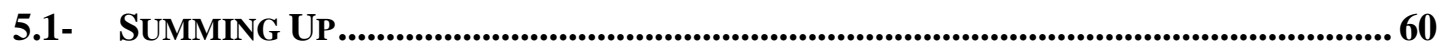


5.2- THE ESCHATOLOGY OF THE ARAB SPRING .................................................................61

5.3- IMPACT OF VARIED VARIABLES..................................................................................66 66

5.4- THE CURSE OF SISYPHUS ................................................................................................. 71

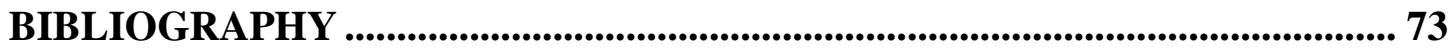




\section{LIST OF ACRONYMS}

$\begin{array}{ll}\text { EU } & \text { European Union } \\ \text { GCC } & \text { Gulf Cooperation Council } \\ \text { GDP } & \text { Gross Domestic Product } \\ \text { MENA } & \text { Middle East and North Africa } \\ \text { NATO } & \text { North Atlantic Treaty Organization } \\ \text { NTC } & \text { National Transitional Council } \\ \text { U.N. } & \text { United Nations } \\ \text { U.K. } & \text { United Kingdom } \\ \text { U.S. } & \text { United States of America } \\ \text { WWII } & \text { Second World War }\end{array}$




\section{LIST OF TABLES}

Table 4.1 Richest Countries in the World as of $2012 \quad 50$

Table 4.2 Deaths in the Arab Awakening 53

Table 5.1 Results of Interaction between Internal and External Variables on

Regime Outcome 66

Table 5.2 Assessing Implications of the Arab Spring 68 


\section{LIST OF FIGURES}

$\begin{array}{lll}\text { Figure } 3.1 & \text { Libya’s Geographic Map } & 28\end{array}$

Figure 3.2 Comparison between NATO and Pro-Qaddafi Forces 32

Figure 4.1 Map of the Persian Gulf (page 56)

Figure 5.1 Habib Bourguiba Mausoleum in Monastir 63

Figure 5.2 Regional and International Military and Humanitarian Contribution in $\begin{array}{ll}\text { Libya and Bahrain } & 70\end{array}$ 


\section{CHAPTER ONE}

\section{INTRODUCTION}

\section{1- Introduction}

This thesis will explore the role of the external context on prospects for democratization after the recent Arab uprisings. Academic and policy specialists have long debated various approaches in an attempt to find which factor explains best democratic transitions. Guillermo O'Donnell and Philippe Schmitter (1986) drew their answers from the importance of the elites' idiosyncratic calculations. Larry Diamond, Juan Linz, and Seymour Lipset (1989) emphasized the importance of structural facets in developing explanations for specific countries' mode of transition. Moreover, Staffan Lindberg (2009) examined democratization from the lens of repeated contested elections. Lindberg re-visits elections as a causal variable for democratization. These explanations of democratic transitions focus mainly on internal factors. On the other hand, this thesis will contribute to the democratization debate by highlighting the importance of a fourth paradigm in the study of democratization: the role of external variables in democratic transitions. Taking Bahrain and Libya as case studies, and unpacking the role of the external (international and regional) context, this thesis examines an overlooked transition paradigm in the study of democratization process in the Arab world.

Democratization does not necessitate preliminary requirements such as nationbuilding or vibrant civil society (Whitehead 2002). However, when theorizing about the applicability of democratization, there are various challenges and "part of the challenge of democratization is that every nation that has already made the journey 
seems to have followed a somewhat different path, and there is no set process for building a democracy" (Pollack et al. 2011: 88). Nevertheless, Stephen Grand argues that "democratization is not easy, and it is not quick. To glimpse where the politics of the Middle East may travel, the best guide is the experience of other regions of the world that have gone down the path of democratic reform" (Grand in Pollack et al. 2011: 21). Resilient to the waves of democratization, the authoritarian regimes of the Middle East were and are the center of scholarly debates. From co-optation, neopatrimonialism, clientalism, and non-accountability methods of Arab politics, the theories of Middle Eastern exceptionalism revolved around political culture, the black gold curse, colonial legacies, and the robustness of coercive apparatuses.

Nevertheless, the examination of the role of domestic variables in instigating democratic transitions has been overly debated. From arguments of O'Donnell and Schmitter, Diamond, Linz, and Lipset, to Staffan Lindberg, the major paradigms have revolved around the role of idiosyncratic calculations of elites, the structure of the state, and repeated elections. Therefore, it is only through revisiting the old and historical assumptions regarding Middle Eastern exceptionalism and the major paradigms of democratic transition that, we, scholars and practitioners, who witnessed the Arab Spring, can learn from precedential assumptions. "The vast intertwined problems of the Arab world will not magically disappear when the old regimes fall and new ones take their places" (Pollack et al. 2011: 61), but it is fundamental to highlight the role of external variables- as a mode of transition paradigm- in the Arab Spring.

In a pre-Bouazizi Arab world, few social movements occurred that were merely short-lived. The 1987-1989 social movements that transpired across Middle Eastern countries - Algeria, Lebanon, Morocco, Jordan, and Egypt - were brought to 
an end through coercive measures and promised reforms. On the other hand, "the political developments of the post-2010 period are unprecedented in their depth and breadth" (Brand 2013: 1). At the end of 2010, Arabs decided to celebrate 2011 in their own way. Making the MENA region a hotbed of defiance, the long-ruled leaders of the Middle East were challenged in an unparalleled and exceptional manner. "[The] furious sense of grievance across the Arab world that finally boiled over in the winter and spring of 2011" (Pollack et al. 2011: 2) is unprecedented in both its taken course of action and its outcome.

Moreover, "the current wave of political unrest in the Arab world has shown once again the difficulties of predicting complex socio-political events" (Behr 2012: 18). The Arab Spring was not only unprecedented in its depth but also in the level and rate of the role of external variables, which was fundamental in shifting the course of political transitions. Almost two and a half years after the self-imolation of the Tunisian Bouazizi, "the tremors [of Arab discontent] can still be felt, and no one is quite certain when the aftershocks will end, or when another shock wave of popular unrest might occur" (Pollack et al. 2011: 1)

With the exception of Bahrain, the regimes mostly affected by waves of Arab discontent were not monarchies. However, "on a more political level, we really need to understand the collective, interconnected reactions of Saudi Arabia and other GCC monarchies and billionaires to events across the region and in individual instances (Libya, Egypt, Bahrain, Yemen, and Syria) including secretive financial channels as well as official policy positions and backing for some parties against others" (Carapico 2012: 17). Not only is the role of Saudi Arabia in the Bahraini unrest an important variable in examining the variation in the impact of external dynamics but also NATO's intervention in Libya under the umbrella of humanitarian intervention is 
fundamental. Since its inception in 2005, the Responsibility to Protect (R2P) had never been implemented through a Security Council resolution. The UN Security Council Resolution 1973 was pioneering not only in authorizing NATO's intervention in Libya but also in adopting R2P as a fundamental norm for avoiding a Libyan massacre.

Daniel Byman and Kenneth Pollack argue that "the impact of the Arab Spring reaches far beyond the countries in transition, and perhaps no outside powers are more affected than those that border the Arab world. They are fast finding that through geography, history, national interests, or ideology - the Arab Spring is reshaping the region in which we live" (Byman \& Pollack in Pollack et al. 2011: 243). Studying the varied role of regional and international response in Libya and Bahrain highlights the role of external dynamics in promoting regime maintenance and in orchestrating regime breakdown. Throughout the events of Arab discontent, it was evident that the United States had a less of an active role because "the United States' strategic involvement in the Middle East is rooted in two sources: a hegemonic interest in secure and stable oil markets, and an overarching ideological commitment to the state of Israel that is reinforced by significant domestic pressures" (Kitchen 2012: 53). The interim result after any revolt or uprising is precarious. As the Middle East approaches the third year of the 2010 events, Libya faces concrete challenges in terms of control, security, and legitimacy whereas Bahrainis remain in a disenchanted discontent every now and then.

\section{2- $\quad$ Research Question}

The Arab world is known for its vulnerability to external interference. The effect of the external dynamics on the Middle East have resonated across the years, 
"as was the case before the end of the Cold War, the regional and international environment have been an omnipresent factor in the decision-making of Middle East regimes" (Brynen, Moore, Salloukh, \& Zahar 2012: 278). Nevertheless, the strategic role of external factors has continued to play an important role after the end of the Cold War. When the waves of Arab uprisings gradually started to spread across the region, the regional and international reactions towards the Arab Spring varied. Taking Libya and Bahrain as case studies and the historical sociology approach as a theoretical framework, helps to explain the role played by external variables in determining authoritarian regime breakdown or maintenance. Placing the external variables as the independent variable and the dependent variable as regime breakdown or regime maintenance, a number of variables can then be operationalized, including oil, geopolitical location, alliances, and foreign policy. Examining the two case studies comparatively, the research question thus becomes: What explains variations in the impact of external variables on authoritarian regime breakdown or maintenance?

\section{3- $\quad$ Methodology}

Relying on historians as a source of information provides a good basis for understanding the past; nevertheless, it is not the only solution. Overemphasizing the past prevents us from offering viable explanations of the present. Therefore, aside from using an eclectic approach for understanding and interpreting different concepts and assumptions, Fred Halliday's (2005) international historical sociology is used in this thesis. The international historical sociology method is a dynamic approach that opens up major historical matters. This approach lists the state, ideology, society, and institutions (political, social, and religious) as core components within its framework. 
Analysis of the state from a perspective of internal state-society relations and external state-state relation is the two level operation of historical sociology.

The two case studies in this thesis are Libya and Bahrain. After the uprisings in Tunisia and Egypt overturned Ben Ali and Mubarak respectively, massive social unrest spread across Libya. However, unlike Tunisia and Egypt, the brigades known as thuwar in Libya were assisted in their campaign against Qaddafi. The North Atlantic Treaty Organization, NATO, led a seven-month bombing campaign in Libya. Analysis of the major military forces within NATO shows that the major forces are former colonial powers in Africa. On February 2012, the Libyans marked the anniversary of the uprising that led to the overthrow of Muammar Qaddafi's fortyyear rule. On the other hand, the Bahraini uprising started in February 2011, the first protests in an oil-rich country in the Gulf. The peaceful uprising in Manama was short-lived, however. With the authorization of the Gulf Cooperation Council, Saudi Arabian troops crossed into Bahrain in a joint-force to support the regime against the uprising. Formed in 1981 as a security and economic cooperation among the Gulf countries against the threat of the Persian neighbor, the GCC played a significant role in smashing the uprising in Bahrain.

During the Arab uprising, the adversarial balance of power was manipulated for the maintenance of the authoritarian regime, as in the case of Bahrain. However, in the case of Libya, the external variable played a positive role in shifting the situation towards breaking down the authoritarian regime of Qaddafi. Therefore, in the two cases, Libya and Bahrain, the external variable tilted the dynamics of power distribution within the respective states.

The Middle Eastern interconnected populist movement in demand of change is a new phenomenon. What has happened? What are the common problems between 
Middle Eastern countries? Are the reasons related to economic deficiency? Or is it the lack of legitimacy and trust between the ruled and the ruling? Whilst acknowledging that each country differs in its historical, political, economic, and social environment, this thesis will examine the case of Libya and Bahrain. Therefore, this thesis will compare the case of Libya and Bahrain in light of international historical sociology in order to assess the difference in the role of the external variable on regime change. A number of variables are operationalized: oil, geopolitical location, alliances, and foreign policy.

Relevant secondary data ranging from books to scholarly articles has been collected, analyzed, and interpreted. In an attempt to formulate tentative conclusions concerning the overlooked paradigm, the external context, and its role in regime change, various assumptions, concepts, and hypotheses in relation to the issue of democratization will be explained.

There have been various works concerning the issue of democracy and democratic transitions. Nevertheless, the issue of democratization is a study that entails different dimensions. This thesis will re-visit the study of democratization in light of the Arab uprisings that occurred in 2010 in the Middle East. The Arab Awakening known as the Arab Spring is still a recent phenomenon, and many events are still unstably changing in cases of study such as Egypt, Syria, Tunisia, Libya, Yemen, and Bahrain. Democracy and democratization are two key concepts that cannot but be explained differently among scholars and practitioners (Whitehead 2002). In this thesis, the definition of democratization illustrated by Whitehead will be adopted. Whitehead believes that democratization is not the process that begins after ousting dictators and ends by competitive elections; democratization is a long and dynamic process of social construction. 


\section{4- Map of the Thesis}

This thesis is divided into five chapters. After introducing the topic that the thesis examines, the second chapter examines the three main transition paradigms, elites' idiosyncratic calculations, structural aspects, and elections, and then introduces the external context as a fourth paradigm. The third chapter applies the case of Libya to the causality of the international framework that will lead for a better understanding of how the external variables lead to authoritarian regime breakdown. The fourth chapter assesses how the external variables lead to authoritarian regime maintenance, as in the case of Bahrain. The last chapter is a summary of the previous chapters whilst offering the results of the debated transition paradigms in the Arab world. 


\title{
CHAPTER TWO
}

\section{RECONSIDERING AN OVERLOOKED}

\section{TRANSITION PARADIGM}

\author{
"Democratization can be imagined and attempted in all corners
}

of the globe" - Laurence Whitehead

\section{1- Introduction}

In light of identifying insurmountable domestic obstacles in the face of democratization, much has been written to explain the persistence of authoritarianism in Arab politics. Scholars and practitioners argue that for some time before the Arab Spring, "much of the scholarly attention [...] shifted from trying to understand the potential sources of reform in the Middle East to trying to understand the roots of authoritarian persistence in the region" (Brynen, Moore, Salloukh, \& Zahar 2012: 7). The studies of Arab states focused on the regimes' mechanism to co-opt and contain popular opposition (Gause 2011). As much as scholarly works shifted towards building theories of authoritarian persistence, "we in the academic community made assumptions that, as valid as they might have been in the past, turned out to be wrong in 2011" (Gause 2011: 82). Therefore, no one in the academic community predicted the Arab uprisings that started in December 2010. Nevertheless, when the uprisings in the Middle East occurred, many observers discussed optimistically the possibility of witnessing a new phenomenon in the region, a phenomenon whereby power can finally be by the people and for the people. Sovereignty and self-determination became fantasized notions ready to be realistically depicted in the Arab world through street protests that spread gradually from Tunisia on 18 December 2010 to Egypt, 
Libya, Syria, Bahrain, and Yemen. "Democracy, after all, means rule by the people" (Shedler in Lindberg 2009: 315) and although dictators in authoritarian countries such as Tunisia, Egypt, and Libya, were overthrown, question marks still persists about the possibility of democratization in the Arab world.

Democracy and democratization are two key concepts that cannot but be explained differently among scholars and practitioners (Whitehead 2002). Therefore, democratization is not the process that begins after ousting dictators and ends by competitive elections; it is a long and dynamic process of social construction whereas "democracy is best understood not as a predetermined end-state, but as a long-term and somewhat open-ended outcome, not just as a feasible equilibrium but as a socially desirable and imaginary future" (Whitehead 2002: 3). An overlooked transition paradigm in the study of democratization is the role of external variables. Several democratization transition paradigms have been discussed; however, all the variables analyzed in the causal relation have focused on internal dynamics. Therefore, the focus and priority should be towards "the analysis of the conditions that lead to the breakdown of authoritarian regimes, to the process of transition from authoritarian to democratic regimes" (Linz and Stepan 1978: ix). Today, thirty-five years after Linz and Stepan's argument, the process of democratic transition leading to regime breakdown or regime maintenance should be highlighted as a priority in the study of democratization.

This chapter identifies three major transition paradigms in the study of democratization. It analyzes these transition paradigms and then categorizes them as explanations of democratic transitions focusing mainly on internal factors. The chapter lists and examines the major explanations of the Arab world's resistance to democratic transitions in terms of internal and external variables. Nevertheless, the 
chapter's main focus is to contribute to the democratization debate by highlighting an overlooked fourth transition paradigm in the study of democratization: the role of external variables in democratic transitions.

\section{2- Resistance to Democratic Transition}

Many scholars have attempted to explain the persistence of authoritarianism in the Middle East using various variables. Political culture, rentierism, security, gender inequality, colonial legacy, coercive agencies, and many other variables have been

used to explain the impediments to democracy in the Middle East. Nevertheless, many scholars missed predicting the massive uprisings that started in Tunisia on 18 December 2010.

These explanations of the Arab world's resistance to democratic transitions focus mainly on internal factors. In an age where democratic and liberal values are the trend, why has the authoritarian regimes in the Arab world been resistant to change? Deploying a political culture explanation of Arab politics, many scholars have not appropriately used this approach (Hudson 1995). With authoritarianism being the primary variable to be examined, explanations were and are still given in terms of three main approaches: socioeconomic, socio-cultural, and institutional. Believing that political culture is a pivotal variable necessary for explaining important aspects of Arab politics, Hudson argued for the need to carefully bring back the political culture approach is a must (Hudson 1995). He suggested that bringing back a sophisticatedly empirical political culture based on close behavioral examination and less cultural generalization is very important for understanding conditions such as democracy and legitimacy in the Arab world (Hudson 1995). 
On the other hand, it is important to shed light on the negative consequences to the study of Arab politics due to political culture explanations (Anderson 1995). In an attempt to prove the fallacies of this approach, attitudes compatible with democracy are a mere result of adaptation to democratic institutions and social transformations (Anderson 1995). Therefore, explaining the absence of democracy by invoking the presence of patrimonial patterns, Islam, violence, or the presence of something else is no longer acceptable. Nevertheless, with the absence of democracy in the Arab world remarkably shining more than ever, the nature of regimes in the Arab world cannot be understood fully except through analyzing their political economy (Anderson 1995). The context of political economy can be depicted as an internal or an external variable; however, the character of integration of Arab states into the world economy serves as an important external variable for understanding the non-democratic nature of Arab regimes.

In an attempt to answer the question as to why the MENA region has been resistant to change, Eva Bellin argues that it is neither cultural nor socio-economic factors that have made the region exceptionally resistant to democratic transition (Bellin 2005). The coercive aptitude of the state offers a proper explanation in terms of why there has been limited popular mobilization in demand for democratic reforms. In contrast to what Lisa Anderson argues, Bellin highlights the fact that it is not the absence of cultural and socioeconomic pre-requisites that has made the MENA exceptional to democracy, rather it is the robustness of their institutions (Bellin 2005). In a reconsidered article, Bellin argues that the coercive aptitude of the states is an important variable in determining the variation in repressing popular protests (Bellin 2012). Nevertheless, the Arab Spring proved the exceptional arguments of regimes' coercive robustness as a falsifiable variable. In a moment of 
outrageous defiance, authoritarian regimes' tactics for self-preservation could not withhold the demands of populist movements.

Moreover, many scholars have tried to distance themselves from examining the role of oil as an impediment to democracy in some Middle Eastern countries. The nature of the ruling families and regime strategy has had a role in impeding democratization in the Middle East and North Africa. In order to explain monarchical survival and the failure of democratization in the Middle East, one must look at the nature and the role of monarchical families (Herb 1999). Therefore, the family coalition in ruling the state is what best explains the resilience of the monarchical regimes in the Middle East (Herb 1999). Control of state institutions by the ruling family is the type of regime known as dynastic monarchy. Herb argues that all dynastic monarchies in the Middle East are resilient to change (Herb 1999). Nevertheless, the dynastic monarchies of the Middle East such as Bahrain, Saudi Arabia, Jordan, and Morocco have proved Herb's causality for regimes' resilience to change as wrong. Despite the fact that the uprisings in the monarchical regimes of the Middle East- with the exception of Bahrain- have illustrated multiple sets of variables for maintenance of regime stability and security, most notably, the regime's tactics to crush protestors.

Therefore, various domestic variables were endorsed as explanations for the Arab world's resistance to democratization. There are a number of variables that many scholars tried to use in order to explain why some Middle Eastern monarchies failed and others not (Herb 1999). Hazem Beblawi used the factor of oil revenues to explain survival strategies of monarchies (Beblawi 1999). Other scholars used the level of opposition, level of education, power of the army, foreign powers' protection, and the existence of parliaments to explain regime survival (Herb 1999). However, 
refuting all of these explanations in understanding what makes monarchies resilient is essential (Herb 1999). Herb contends that family succession, family coalition/unity, and factors of non-accountability and clientelistic relation between state and society are features explaining the dynastic monarchies' resilience for change (Herb 1999). However, Muammar Qaddafi's techniques of repression, censorship, and corruption did not withhold the Libyans from revolting against him. Akram Al Turk argue, "when the Arab Spring swept across Libya, pulling thousands of frustrated people into the streets, including key tribal leaders and defectors from the regime, the revolution was strong enough to immediately cause the collapse of the weak Libyan state, but not enough to immediately oust Qaddafi and his loyalists altogether" (Al Turk in Pollack et al. 2011: 119). Therefore, with an international intervention through NATO, the battle's outcome was tipped in favor of the populist protestors and this proved that oil wealth could not buy Qaddafi his regime stability.

From political culture, the robustness of coercive institutions, family coalitions, the black gold curse, to levels of state control, internal variables were usually offered as explanations to understand the persistence of authoritarianism in the Middle East. Nevertheless, after around twenty-five years from the most modern political transformation in Eastern Europe, Africa, and Asia - that featured extensive civil opposition against single party rule system - the lack of reform potentiality in the Middle East is still being explained in terms of internal contexts. For example, Valerie Bunce and Sharon Wolchik illustrated that "with the help of particularly intensive international democracy assistance, the attraction of European Union membership, and more capable civil societies, the East European countries have largely fared well, becoming both successful capitalist economies and relatively democratic in two waves of electoral revolutions" (Lindberg 2009: 4). Therefore, the role of external 
variables as a mode of transition has been extensively overlooked in the study of democratization in the Arab world. A double-edged sword, external dynamics as a mode of transition can be a factor both in democratization and in the persistence of authoritarianism.

\section{3- Transition Paradigms in the Study of Democratization}

Academic and policy specialists have long debated various approaches in an attempt to find which factor explains best democratic transitions. One of the first books in any language that methodically and comparatively focused on the transitional process from authoritarian regimes is that of Guillermo O'Donnell, Philippe Schmitter, and Laurence Whitehead (1986). Whilst asking questions about the transition process in Latin American and Southern European countries, O'Donnell, Schmitter, and Whitehead draw their answers from the importance of the elites' idiosyncratic calculations. Depicting the nested game between internal and external factors, Whitehead argued that "in all peacetime cases ... internal forces were of primary importance in determining the course and outcome of the transition attempt, and international factors played only a secondary role" (O'Donnell, Schmitter, \& Whitehead 1986: 4). Focusing on the importance of elites' perception paradigm, and refusing to accept the argument that there are economic and social prerequisites for democratization, the most important key during democratic transition process is the "role of elite interaction and strategic choice" (Schmitter 2010: 18).

On the other hand, a second transition paradigm is offered by Larry Diamond, Juan Linz, and Seymour Lipset, who emphasize the importance of structural facets in developing explanations for specific countries' mode of transition (Diamond, Linz, \& Lipset 1989). Moreover, maintaining democracy would require "an authoritative, 
effective state, but there is often tension between authority and control, between capacity and domination" (Diamond, Linz, \& Lipset 1989: 27). Through its strong institutions, the state's ability to maintain and expand public order is the most important determinant of democratic stability. Nevertheless, the two fundamental features of state structure is the ability to intervene and control its economy (Diamond, Linz, \& Lipset 1989). Agreeing with the arguments presented twenty-three years ago, "institutions are particularly important because they reflect and embed social realities, as well as enabling and constraining the social and political choices that actors have within political systems" (Brynen, Moore, Salloukh, \& Zahar 2012: 9).

Moreover, a third transition paradigm is offered by Staffan Lindberg, who believe that democratization is best looked upon from the lens of repeated contested elections (Lindberg 2009). Basing his arguments on the countries that experienced the third wave of democratization, Lindberg re-visits elections as a causal variable for democratization whereby he asserts that "elections are not only indicators but also a mode of transition themselves, whereby electoral processes and incentives under certain conditions play causal roles in furthering democratization" (Lindberg 2009: $\mathrm{xxi}$. But does repeated elections as a causal variable always leads to democratization? The three major indicators for the democratic quality of elections in a country are the level of participation, competition, and legitimacy (Lindberg 2009). Therefore, the major argument advocated is that the more elections are held, the more the society and the regime becomes democratic, and "Ghana's recent political history [...] displays a best case scenario in which a series of five transitions from one type of regime to another eventually led to a liberal democracy" (Lindberg 2009: 15). 
There are various theories of transition paradigms that suggest important causal variables in the study of democratization. Nevertheless, elites' perceptions, state structures, and elections have been listed as three major causal variables in the study of democratization that offer explanations of democratic transitions focusing mainly on internal factors. The role of actors and institutions has been configured to be the most important contributor and impediment to transition processes. However, just as elites' idiosyncratic calculations, state structure, and elections can be viewed as a mode of transition for democratization, they can be viewed as factors leading to authoritarianism.

It is true that elite's perceptions offer important explanations of prospects for democracy; however, they cannot be excluded from the geopolitical location, domestic political composition, and history of the country examined. The case of Portugal in 1975 and the Dominican Republic in 1978 are exemplary examples how a mild impulse from the outside can and might impact the transition process to tip the outcome in one way or another (O’Donnell, Schmitter, \& Whitehead 1986). Moreover, arguing in contradiction of the theory of elections as a mode of democratic transition, Jennifer McCoy and Jonathan Hartlyn contended, "there is considerable evidence that simply holding elections under authoritarianism does not necessarily foster democratization" (Lindberg 2009: 47).

\section{4- A Fourth Transition Paradigm}

Few explanations of the Arab world's democratic transition deficit focus on the role of external variables. Scholars such as Basilios Tsingos argued that, "the role of international factors in the democratization process has become the focus of considerable scholarly attention in the wake of the events in Eastern Europe in 1989" 
(Whitehead 1996: 315). Moreover, the explanations invoking international factor have focused on either democracy promotion or on the effects of democratization in countries neighboring authoritarian regimes (Whitehead 2002). Many scholars and practitioners anticipated democratic transitions to occur in the wake of the end of the Cold War. It was only in the aftermath of the events of 9/11 that international pressure on incumbents in Arab authoritarian regimes led to minor political transformation such as allowing multiparty elections. Oliver Schlumberger asserted that, "the mode of governance in the Arab world is of prime importance in the post-911 world because of its direct relevance to international peace and security and to the relations of Western governments with their Arab counterparts" (Schlumberger 2007: 1).

Among the fifteen findings that Schmitter identifies as lessons for democratization over the last twenty-five years, he asserts that the time, mode, and result of the transition are determined notably by the international context (Schmitter 2010). Therefore, the basis for the causality of the international context is variably different according to "the size, resource base, regional context, geostrategic location, and alliance structure of the country involved" (Schmitter 2010: 27).

Among the six monarchies in the Middle East, Bahrain was the only one that witnessed major social upheavals. The Kingdom of Saudi Arabia, Oman, and Kuwait witnessed minor social movements, which faded before they even started. As for Qatar, its peaceful and homogenous environment remained isolated from the domino effect of the Arab Spring. So what explains the resilience of these regimes? Oil wealth should not be an excuse to dismiss the possibility of democracy in the Middle East (Herb 2005). Nevertheless, the importance of regional factors in explaining the persistence of authoritarianism in the Middle East should not be avoided. The cases of Libya and Bahrain illustrate that oil wealth is not an impediment for breaking walls of 
fear and repression. Nevertheless, both cases show how the regional and international variables impact the outcome of populist uprisings in demand for reform.

Furthermore, the distinctiveness of the Middle East as a regime type is attributed to regime strategy (Gause 2000). The survival of monarchy as a regime type in the Middle East cannot be attributed to domestic political culture factors such as Islam and tribalism. Islam and tribalism are factors shared by countries where monarchy as a regime type has failed and in others have survived. Therefore, the position of the Arabian Peninsula in the regional security system and the international political economy are one of the most important external factors to examine. Nevertheless, foreign power assistance and oil revenues guarantee protection and act as an asset to domestic usages (Gause 2000). Despite that oil wealth has allowed the fragile monarchical regimes in the Middle East to surmount all regional and domestic obstacles, the rentier state theory does not make rentier states immune from the democratization syndrome (Gause 2000). Therefore, with different range of interactions, "many years of authoritarian persistence in the Arab world are best explained as the result of the catalytic and synergistic interactions among a set of variables operating at different levels" (Brynen, Moore, Salloukh, \& Zahar 2012: 289).

In a pioneering study, Pete Moore believes that academics and policy specialists have analyzed democratization in the Arab world by approaching the internal/national level through concentrating on state-society relations and institutional dynamics (Moore 1994). In the 1980s and 1990s, research on democratization and the modes of transit-ology centered on the role of internal variables; on the contrary, Moore highlights the positive and negative role played by 
the external factor, regional and international, in hindering or inviting democratization in Arab world (Moore 1994).

Moreover, external factors have exhibited primary influence on Middle Eastern regimes in three respects: on-going conflict, democracy promotion, and spread of Islamism (Brynen, Moore, Salloukh, \& Zahar 2012). As for the case of democracy promotion, it is one of the methods adopted for achieving specific foreign policy objectives (Whitehead 1996). With vast history of democracy promotion, "Washington needs to recognize that democracy promotion is as much a political as a technical endeavor" (Grand in Pollack et al. 2011: 28). The United States of America has practiced democracy promotion in almost three extreme examples of democracy imposition: through invasion, through incorporation, and through intimidation (Whitehead 1996). Therefore, democracy promotion is one of the methods used for influencing democratization; however, the successful establishment of democratization in the Middle East "will depend in good measure on the existence of public demand for reform and democracy" (Grand in Pollack et al. 2011: 26).

In an attempt to answer the riddle of the Arab world's democratic deficit, there are three crucial factors that lead to either democracy enforcement or the isolation of autocratic regimes: geopolitics, oil, and domestic political structure (Diamond 2010). The dissemination of threat from the on-going Arab-Israeli conflict and from neighboring Arab states is a major factor verifying authoritarianism (Diamond 2010). Whilst conceding to the role of regional context argument by Diamond, the Middle East is "not only [...] characterized by high permeability, but it is also afflicted with considerable levels of regional conflict" (Brynen, Moore, Salloukh, \& Zahar 2012: 257). Therefore, the development of armed forces as an effect caused by conflicts leads to the maintenance/survival of authoritarian regimes. 
Nevertheless, policy specialists and researchers have been misinterpreting the Arab world after the terrorist attacks of September 11, 2001 (Heydemann 2007). Democracy promotion has led to the resilience of authoritarian regimes in the Arab world (Heydemann 2007). Previously, academics have argued in favor of democracy promotion whereby "the simplest and most fundamental motive for the promotion of democracy is to extend to foreigners the benefit of a system that is valued at home" (O'Donnell, Schmitter, \& Whitehead 1986: 10). On the other hand, the international variable - democracy promotion - can also be a variable contributing to the Arab world's resilience (Heydemann 2007). While expressing evident and potent repressions, authoritarian regimes have upgraded their strategies of domination to adjust to external and domestic pressure.

Despite the abundant democratization deficit theories about the Middle East and the comparative analysis about authoritarian regimes, academics have missed predicting the Arab Spring because they were overwhelmed with pre-determining the factors inhibiting transition away from authoritarian regimes. Predominant explanations focused on existing internal variables whereby "in much of the Middle East democratization may be harder to imagine, in part because of the apparent strength of oil-financed monarchies (such as the Saudi regime), but also because of the conflict with Israel, and most basically because of an asserted incompatibility between Islam and Western Liberalism" (Whitehead 2002: 190).

There are no specific instructions to follow in order to achieve democracy that is applicable at all times and to all cases. The role played by external variables has multiple outcomes and paths. Analyzing the international factor of democratization may come in three major forms: contagion, control, and consent (Whitehead 1996). Arguing that each form focuses on specific variables- contagion focuses solely on 
geographic location of country studied, control focuses on motivation of actors, and consent focuses on interaction between international and internal politics- Whitehead contends that at most times, there is significant overlay between the three forms (Whitehead 1996). A fundamental and recent form of international influence should be added as a fourth category to Whitehead's three categories (Schmitter in Whitehead 1996). Conditionality is the most recent dimension of international influence, which has the use of coercion as its fundamental hallmark.

Nevertheless, some scholars, such as Schmitter, underscore the importance of internal dynamics on the process of democratic transition. He contended that "regime change tends to be a domestic affair; democratization is a domestic affair par excellence" (Schmitter in Whitehead 1996: 27). As a conclusion of the different conceptualizations of the dynamics and influences of the international dimension:

Grosso modo, there seem to be four ways of conceptualizing the dynamics of interaction between the international sub-contexts of power and influence and the varied national cases of democratization. One can adopt a basically functionalist view and interpret the outcome in terms of an adaptation of the latter to independent and exorable trends in the former. Alternatively, the emphasis could be more historically contingent and focus on the impact of discrete events (or even personalities). Or one can place primary emphasis on the complex, temporally structured interaction between cases and assign primary importance to waves of diffusion and imitation. Or one can take a genetic perspective and emphasize the changing nature and importance of the international context upon different stages of the democratization process. None of these four is mutually exclusive; all may eventually contribute to improving our understanding; each will, however, bring up different variables and generate different hypotheses, and may even lead one to different conclusions (Schmitter in Whitehead 1996: 31).

Regardless of the importance of internal variables on democratic transition initiation, course, and outcome, the role of external variables is indispensable in systematically and comparatively contributing to the democratization debate. External dynamics can tip the initiated process, path, and most importantly the outcome of democratic transitions. 
On the other hand, moving away from contagion, control, consent, conditionality, democracy promotion, and regional contexts, there has not been much literature emphasizing on the role of external factors in determining the impact of the democratization transition in authoritarian regimes. Moreover, Charles Powell emphasized the vast literature found on Spain's democratization transition but with no attention oriented towards the international context of the transition process (Whitehead 1996). Much of the theories and explanations revolve around the condensed importance of external factors in consolidating democracy. An example of this can be Schmitter's argument that the link between the international dimension and domestic outcomes is fundamental in the consolidation of democracy because "regardless of the form (control, contagion, consent, or conditionality) that it takes, external intervention will have greater and more lasting effect upon the consolidation of democracy than upon the transition to it" (Schmitter in Whitehead 1996: 40). On the contrary, the external factor has a crucial and fundamental impact on the process of transition because the variation in its impact can lead to regime breakdown or regime maintenance.

\section{5- Conclusion}

Therefore, studying the variation in the impact of external variables cannot but be depicted through the operationalization of a number of variables such as the factor of oil, geopolitical location, alliances, and foreign policy. This chapter assessed the dimensions of three democratic transition paradigms, which has focused on the impact of internal variables and then introduced a fourth transition paradigm; the role of external dynamics. Nevertheless, this chapter emphasized that after the Arab Spring, the different set of internal variables used by scholars and practitioners as the 
reason behind the democratic resilience of Middle Eastern regimes are falsifiable. Taking two distinct case studies, Bahrain and Libya, and unpacking the role of external dynamics in democratic transitions will contribute to the earlier works on transit-ology theories of O'Donnell, Schmitter, Whitehead, Diamond, Linz, Lipset, and Lindberg. Why has the international intervention in Libya led to regime breakdown whereas the regional intervention in Bahrain led to regime maintenance?

The next chapter will examine the case of Libya in order to identify the wideranged external response to the Libyan uprising, which will lead us to identify the causality behind the military intervention that led to regime breakdown. 


\section{CHAPTER THREE}

\section{FROM QADDAFI'S IDIOSYNCRATIC}

\section{CALCULATIONS TO NATO'S AIR-MISSILES \\ "Events, past and present ... are the true, the only reliable teachers of political scientists"- Hannah Arendt}

\subsection{Introduction}

On 23 October 2011, the Chairman of the National Transitional Council of Libya, Mustafa Abdul Jalil, announced from Benghazi Libya's Liberation. The announcement was depicted as the end of four decades of struggle for the Libyans. Calling out for stability and the end of the struggle, Abdul Jalil announced the Islamic Sharia as the principle source of legislation. This unanticipated move by the NTC was seen as a double-edged sword. Focusing on Islamic Sharia as the basic source of legislation and at the same time emphasizing the importance of moderate Islamic rule, the NTC's motive was to balance between the demands of the Libyans and the fears of the West.

This chapter analyzes authoritarian regime breakdown in Libya. Exploring the importance of external dynamics of democratization as a transition paradigm, it examines the major variables such as oil, geopolitical location, alliances, and foreign policy in order to understand why an international response in the form of direct military intervention occurred in Libya but not in other Arab Spring states. Therefore, two case studies, Libya and Bahrain - which will be examined in chapter four - will be analyzed with the aim not to reveal universal truths but rather to understand the different ways that the international level affected authoritarian regime breakdown. 


\subsection{Libya's Frail Independence}

A federal state with a constitutional monarchy headed by King Idriss Al Senussi, the 1951 constitution was the fruit of Libyan independence. Adopting patronage policy to ensure compliance and gain of monetary benefits, Al Senussi's rule was characterized as an extended form of colonialism. With Arab nationalism depicted as the major challenge for Al Senussi, "Libya's journey to independence was shaped more by international than by internal forces, and the local people were little more than bystanders in the deliberations over their fate" (Pargeter 2012: 29).

In 1953-1954, Great Britain and the United States of America were granted extended forms of imperial rights through twenty-year treaties of friendship under which both military facilities and overflying rights were permitted in exchange for economic and monetary aid. Libya's geostrategic location in North Africa was crucial to both powers. For example, "when President Nasser nationalized the Suez Canal in 1956, Britain seriously considered using its Libyan bases to launch attacks against Egypt" (Pargeter 2012: 44). Nevertheless, Idris opposed all demonstrations that occurred against his regime in the early 1950s and 1960s, but "the monarchy [was] generally viewed as having a fairly benign institution" (Pargeter 2012: 48).

Moreover, the role of the British forces in Libya had an indirect effect on Qaddafi's $1^{\text {st }}$ of September 1969 coup. As a young ideologue, Qaddafi had big plans for his country and he knew that joining the Army would be the salvation for his planned revolution. Training Libyan troops to defend their country, the 1957 British Military Academy proved to be pivotal because it was the academy in which the 1964-army recruit, Qaddafi, was trained. With a belated participation in the Six Day War of 1967, and having President Abed El Nasser as an idol, Qaddafi was 
determined to avenge the Arab cause, to wipe clean the Egyptian humiliation, and to attack the allies of Israel. Determined to revolt since school days, Qaddafi convinced his revolution companions Abdelsalam Jalloud, Omar Al-Meheishi, Mustafa Kharroubi, Abu Bakr Younes Jaber, Khweildi Al Humaidi, and others to join the army in order to form what was later known as the First Unionist Officers Movement and the Revolutionary Command Council (Pargeter 2012).

Many argued that it is impossible to imagine Libya without Qaddafi; therefore, it is "impossible to separate four decades of Libyan politics from the rule of Muammar Qaddafi, who first seized power in a military coup in 1969" (Brynen, Moore, Salloukh, \& Zahar 2012: 27). Forcibly living their lives based on the mantra of the Libyan dictator, Libyans were prisoners of Qaddafi's 1974 Green Book, which was a collection of shattered and obscure thoughts and analyses. The Revolutionary Committees Movement, imprinted the nature of post-1969 coup d'état, were tied to the Revolutionary Committees Liaison Office- solely composed of Qaddafi's family members and tribe (Pargeter 2012).

Taking a comparative look at Al Senussi's monarchical rule and Qaddafi's Jamahiriya, one of the most pivots of differences between the two was the type and style of foreign relations conducted with the West. The Socialist People's Libyan Arab Jamahiriya, best known as the State of the Masses, had strained foreign relations with the West throughout of Qaddafi's long rule. On the other hand, King Idris made his best efforts to remain on good terms with his Western allies despite the will of his people. Both Qaddafi and Al Senussi neglected the will of the Libyans. Disregarding the type of regimes' reinforcement mechanism, whether it is through adaptation or through intimidation, "there is no way to govern, administer, dictate, arbitrate, adjudicate, guide, interrogate, or represent a political community, except through 
influencing the understanding of the individuals who compose it" (Whitehead 2002: 48).

There was a varied international response to the Libyan crisis in 1969 and that of 2011. When the coup d'état against the frail king, Al Senussi, was implemented, the call-outs for British help were to no avail because Britain was "engaged in the policy of Harold Wilson's government of progressive withdrawal from its former colonies" (Pargeter 2012: 59). Contrary to the $1^{\text {st }}$ of September coup d'état, the international response to the February $15^{\text {th }}, 2011$ revolution differed with NATO's direct military intervention because "NATO intervention certainly prevented the regime from overrunning Benghazi in March, but was unable to deliver a quick military victory for the opposition" (Brynen, Moore, Salloukh, \& Zahar 2012: 29).

\section{3- Libya Is Not Qaddafi}

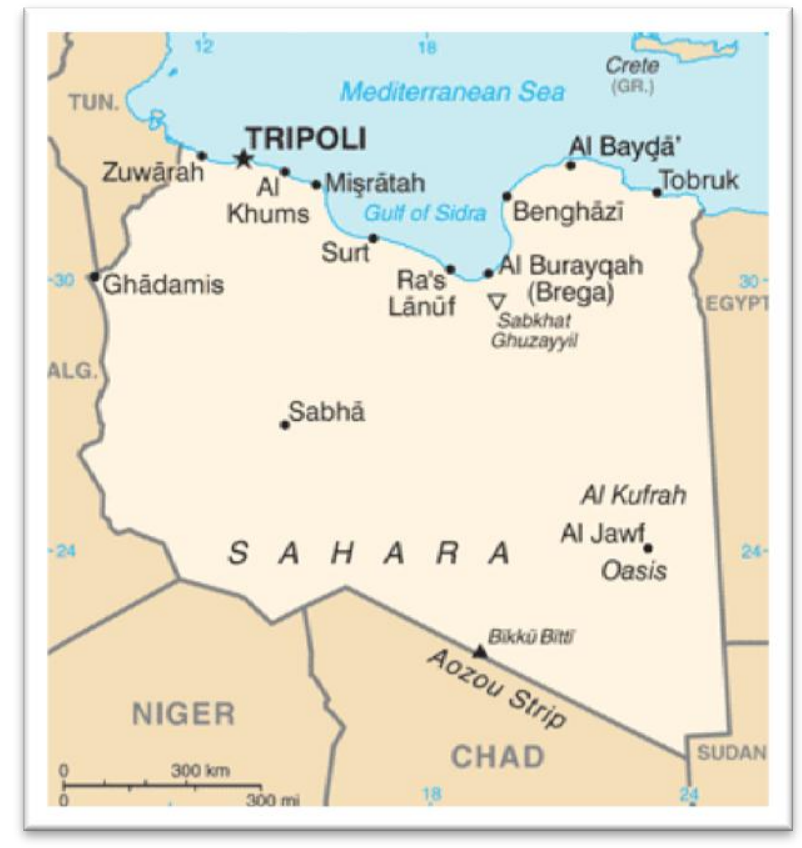

Figure 3.1: Libya's Geographic Map ${ }^{1}$

\footnotetext{
${ }^{1}$ Map retrieved from CIA World Fact book-Libya
} 
Qaddafi described the reason behind the First Unionist Officers Movement in the following manner:

Our souls were in revolt against the backwardness enveloping our country and its land, whose best gifts and riches were being lost through plunder, and against the isolation imposed on our people in vain attempt to hold it back from the path of the Arab people and from its greatest cause (First 1974: 102).

The anti-imperialist Qaddafi made sure to purify Libyan soil by closing all British and American military bases and nationalizing its oil. Therefore, "Libyan politics and administration were dependent on the whims of the country's peculiar dictator and his apparent aversion to strong and permanent institutions" (Brynen, Moore, Salloukh, \& Zahar 2012: 27). Having his tribe and family members as key beneficiaries of the country's oil wealth, “Libya's oil wealth - accounting for around 95 percent of export earnings and 25 percent of GDP, and providing for 60 percent of government wages undoubtedly played a role in sustaining the Qaddafi dictatorship" (Brynen, Moore, Salloukh, \& Zahar 2012: 28). For such reasons, the corrupt regime of Qaddafi had long instigated the rage of youth due to high levels of unemployment. Whilst taking into consideration the socioeconomic and political forces in Libya, "this revolution [in 2011] did not occur in vacuum. It was inspired and spurred on by the momentous events that were shaking the entire region" (Pargeter 2012: 1).

A self-promoted Colonel and Commander of the Armed Forces, Qaddafi's multifaceted security battalions were effectively trained to forcibly crush any opposition; however, after the Arab Spring's Tunisian 'Jasmine Revolution' and the Egyptian 'January $25^{\text {th }}$ Revolution', Libya was geographically surrounded by youthful vibes in demand for change (refer to Figure 3.1). Pollack argues that "with the strong dictatorships in Tunisia and Egypt overthrown, it was perhaps inevitable that the dysfunctional dictatorship lying between them- Libya- would face a similar 
challenge" (Pollack et al. 2011: 4). Despite the fact that more than three attempted revolutions occurred against Qaddafi in 1969, 1976, 1984, and early 1990s, "the Libyan uprising that erupted in February 2011 was fundamentally rooted in socioeconomic and political dissatisfaction, but was also clearly inspired by events in Tunisia and Egypt” (Brynen, Moore, Salloukh, \& Zahar 2012: 28).

\section{4- $\quad \underline{\text { A New Dawn }}$}

On 1 September 1969, Qaddafi addressed his people:

People of Libya! In response to your own free will, fulfilling your most heartfelt wishes, answering your incessant demands for change and regeneration and your longing to strive towards these ends, listening to your incitement to rebel, your armed forces have taken the overthrow of the reactionary and corrupt regime, the stench of which has sickened and horrified us all... From this day forward Libya is free, self-governing republic... She will advance on the road to freedom, the path of unity and social justice, guaranteeing equality to all her citizens and throwing wide in front of them the gates of honest employment where injustice and exploitation will be banished, where no one will count himself master or servant, and where he will be free, brothers within a society in which, with God's help, prosperity and equality will be seen to rule us all (Mirella Bianco 1974: 65).

Ironically, the people of Libya might have recalled the Brother Leader's words of revolution on the 15th of February 2011 when Fathi Terbil was arrested due to his 17 February plans for the 'Day of Rage' as a call-out for reform (Pargeter 2012). However, this time it was the people of Libya who brutally overthrew the idiosyncratic and corrupt regime of Qaddafi, and "the cruelest irony of all in this [...] was that after years of the Colonel calling on the masses to rise up in the service of his revolution, [...] they did so in order to destroy him and all that he had created" (Pargeter 2012: 247). On 15 February, the young Libyan Ahmed Lebderi followed the footsteps of the Tunisian Mohamed Buazizi, who had sparked the Jasmine Revolution 
of Tunisia and ignited the Arab Spring (Pargeter 2012). It is not a coincidence that 17 February was chosen as a day to call out for reforms. That day marked the fourth anniversary of the 17 February 2006 riots in Tripoli against the cartoonish depiction of the Prophet Mohammad which later turned as a demonstration against the regime; an incident that marked the death of more than ten Libyan protestors (Pargeter 2012). Moreover, it is also not a coincidence that one of the most enduring symbols for the 2011 protestors was the Libyan flag of the post-independence - but pre-Qaddafi period, which symbolizes Libya's freedom and independence.

Days after the start of the uprising, Qaddafi's regime realized that the 2011 revolts were not like the 2006 riots. With the opposition acquiring weapons, the fighting between anti-government rebels and Qaddafi's forces centered around Benghazi and Misurata (Vira and Cordesman 2011). Although anti-government forces controlled Benghazi, Bayda, Dema, Tobruk, and Misurata, heavy fighting around these cities tipped the balance in favor of regime forces (Vira and Cordesman 2011). Consequently, and within a month of the Libyan uprising, the international community decided to intervene on the side of the opposition.

Only two days after the United Nations Security Council accepted France's and the United Kingdom's proposal to end immediately the civil strife in Libya through direct military intervention, the modest impetus of the aerial and naval strikes of the NATO forces on March 19, 2011 tipped the balance of power in the Libyan civil conflict. Formed of former colonial powers of Africa, NATO's intervention in Libya, Operation Unified Protector, remained for around nine months (refer to Figure 3.2). Whitehead argues that when the democratic transition "is related to processes of national liberation and assertiveness, the intromission of foreigners can be especially unwelcome-even if, [...] weak domestic political forces may be sorely tempted to 
look for outside help" (Whithead 1996: 41). In the case of Libya's NTC, "the opposition leaders were initially against external military intervention because they felt it would diminish their credibility, but when Qaddafi appeared close to retaking Benghazi and likely reestablishing control, the NTC began pleading for help" (Al Turk in Pollack et al. 2011: 121).

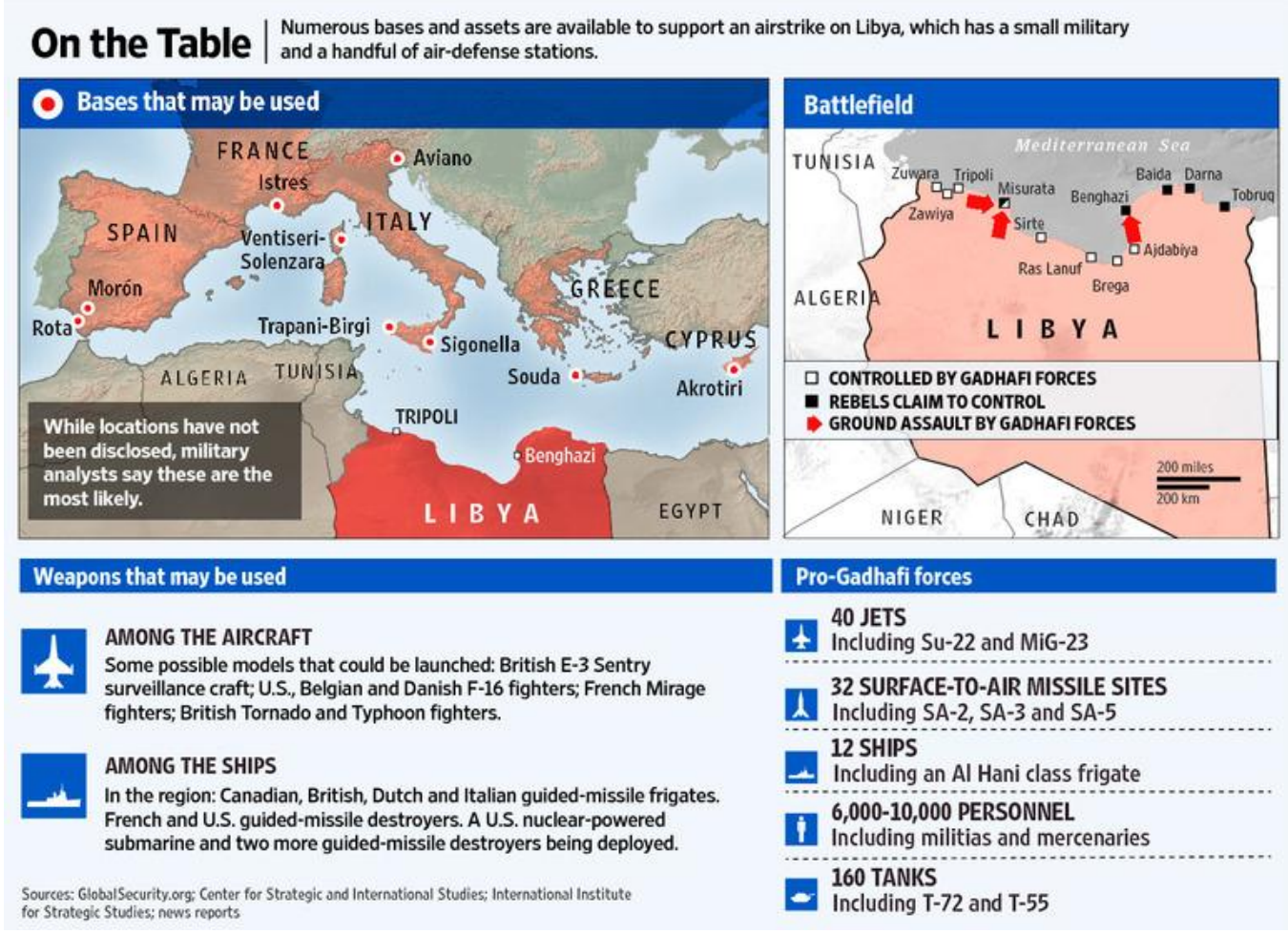

Figure 3.2- Comparison between NATO and Pro-Qaddafi Forces ${ }^{2}$

Facing a merciless fate, Qaddafi was shot dead on 20 October 2011 by the rebellious Libyan people. With Qaddafi's life brought to an end, Libya began the journey of embarking on a new dawn; in other words, "the sun had finally set on the era of Qaddafism” (Pargeter 2012: 247).

\footnotetext{
${ }^{2}$ Retrieved from Task Force, (2012) "Can NATO react to the Arab Spring?" The Henry M. Jackson School of International Studies, pp. 1-301
} 
The four decades of the Brother Leader's rule of Libya ended brutally because "with his unstinting Bedouin pride and uncompromising self-belief, there was no way the colonel was going to step aside and walk away from power gracefully - let alone flee the country" (Pargeter 2012: 226). Excluding himself from any normal political position or title in Libya since 1977, Qaddafi's influence on the Libyan political community was not quite explicit and "indeed a government that neglected to arouse and persuade its subjects or its public would in due course lose their attention and therefore their compliance" (Whitehead 2002: 49).

Furthermore, throughout the four decades of his rule, Qaddafi made sure to create an image of invincibility for himself by expressing that "in the interests of conformity, all political activity outside the official framework of the state was banned- something that culminated in the controversial Law No. 71 of 1972, which made engaging in party politics a crime punishable by death, and which remained in place until the fall of the regime" (Pargeter 2012: 72). On the other hand, today, a Libya without Qaddafi is actually a new dawn because "the idiosyncratic and dictatorial nature of the Qaddafi regime and the weaknesses of long-repressed Libyan civil society also meant that the rebels inherited few organizational resources upon which to build alternative state structures" (Brynen, Moore, Salloukh, \& Zahar 2012: 29).

\section{5- From the Policy of Subversion to Confrontation}

The United States invasion of Grenada in 1983 was a case of democratization imposed by conquest. Since 1945, the United States started adopting "indirect means of leverage over internal political affairs of the independent states of Latin America, the Caribbean, and the Mediterranean" (Whitehead in O'Donnell, Schmitter, and 
Whitehead 1986: 4). Nevertheless, as in the case of Grenada, the United States used direct means of leverage over internal political affairs in Libya whether through imposing economic and political sanctions or through engaging in military operations. Nevertheless, in the 2011 Libyan uprising, the United States' role was to 'lead from behind'.

One of the most personalized and autocratic regimes in the Middle East, Qaddafi's Libya was and is a priority to Washington because "policy makers in Washington saw Libya, together with the remainder of North Africa and the Middle East, as falling within a highly sensitive security zone" (St. John 2002: 3). Influenced by the forces of the past, Libya under Qaddafi entered a lacuna of misconducted, misunderstood, and strained relations with the West, in particular with the United States because "the new income [oil revenues] freed the monarchy from its former dependence on foreign base revenues and thus made possible new policies that were inconceivable less than a decade earlier" (St. John 2002: 16).

In the case of Libya, despite that 1977 marked its addition to the list of adversaries to the Pentagon, it was only when direct attacks on US Embassy in Tripoli in 1979 occurred that Libya's diplomatic relations between US and UK were cut-off. Nevertheless, the imposition of sanctions in early 1990s through the United Nations Security Council Resolutions 731, 748, and 883 characterized the United States, United Kingdom, and the three veto powers' confrontational policy towards Libya. "Prior to the decade of the 1980 s, concepts and terms related to rogue or pariah states, backlash or maverick regime, or nuclear outlaws were not in common uses in academic or policy making circles" (St. John 2002: 155). The tension between the United States and Libya was reached when “on 7 January 1986, President Reagan issued Executive orders 12543 and 12544. These orders declared a national state of 
emergency with Libya and imposed broad economic sanctions against Tripoli, including the freezing of Libyan assets in US territories" (Otman \& Karlberg 2007: 43).

Neither the 1986 "swift and effective retribution against the forces of international terrorism" (Laham 2007: 3) nor the United Nations Resolutions over the 1988 case of Lockerbie's Pan Am Flight 103 impeded Qaddafi's adversarial and subversive foreign and national policies. Yet, Libyans were optimistic regarding enhancing relations with the US with every new administration. Ranging between confrontational and covert policies, the United States could not but view Qaddafi "as an unpredictable irritant who would be best out of the way" (Pargeter 2012: 238).

With the end of President Ronald Reagan's eight-year presidency, President George H. W. Bush supported a "covert policy to provide military aid and training to several hundred former Libyan soldiers. Set in motion during the final months of the Reagan administration, this covert operation hoped to use Libyan volunteers captured during the 1988 border fighting between Libya and Chad to destabilize the Qaddafi government" (St. John 2002: 154). On the other hand, with five US successive presidential administrations, the Libyan foreign policy of subversion was not changed. It was not until “ 5 April 1999, 13 years of US sanctions and seven years of UN sanctions, the Libyan government turned over to British authorities two suspects in the terrorist bombing of Pan Am Flight 103" (Otman \& Karlberg 2007: 42). Nevertheless, it was only in December 2003 that the Libyan government announced the abandoning of weapons of mass destruction programs (Pargeter 2012). What were the reasons for the minor reversal in Qaddafi's policies? After Libya's exclusion from the international community for more than eighteen years, Qaddafi was facing the 
threat of Islamism, a rise in socioeconomic challenges, and the U.S. post 9/11 War on Terror strategy.

With declared Western support for the 2011 National Transitional Council, NATO's air missiles were supporting mechanisms for the stated objective because "had NATO not entered the conflict when it did, it is likely that the rebel forces would not have been able to dislodge Qaddafi from the west of the country and would not have prevented him from re-taking the east" (Pargeter 2012: 8). The light and small weapons that spread amongst the Libyan rebels were insufficient to confront the loyal battalions of Qaddafi because "by filling his security battalions with those of his own kith and kin, Qaddafi ensured that their fate was so closely entwined with his own that they were in no position to try to oust him" (Pargeter 2012: 225). France, Italy, Canada, and Germany rushed to recognize the NTC as the legitimate representative of the Libyan people. However, the United States' decision to recognize the NTC was the gate that allowed the flow of monetary support from all Libyan assets that were frozen in US for years.

From accusations of being a supporter of international terrorism, to the subversion policy adopted in Africa, Middle East, and Western Europe, Qaddafi was depicted by the West as a detestable cartoonish character who ruled a state according to his own whimsical thoughts and analyses -which are best known as the Third Universal theory (Laham 2007). From accusations of acquiring weapons of mass destruction to being a supporter of international terrorism, the anti-imperialist Qaddafi knew that the external powers' calculations were to take advantage of the eruption of social discontent on February $15^{\text {th }}$. The only question Qaddafi miscalculated was the extent the foreign powers were ready to interfere in internal Libyan strife. Qaddafi was taken by surprise when almost a month after the social upheaval stayed; the 
international community authorized NATO to undertake direct military attacks because he knew that the Libyan military apparatus was not equipped to face the forces of NATO.

The legal authorization of NATO's intervention in Libya was through the United Nations Security Council, which voted 10 in favor to none against for the need and responsibility to protect the Libyan civilians. Nevertheless, the use of Responsibility to Protect - initiated by the United Nations in 2005 - at most times sparks controversy. Neither limited in scope, time, or duration, NATO's humanitarian intervention under Chapter VII of the United Nations was understood not an infringement of Libya's sovereignty. In a report for the United Nations Secretary General in 2009, Ban Ki Moon, identified the three pillars of $R 2 P$ as follow ${ }^{3}$ :

1. The protection responsibilities of the state

2. International assistance and capacity building

3. Timely and decisive response

With no specific sequence for implementation of these pillars, the international community has a duty to respond in cases of genocide, crimes against humanity, war crimes, and ethnic cleansing when a state fails to protect its civilians. Nevertheless, when it comes to implementing the $3^{\text {rd }}$ pillar, military intervention remains a controversial aspect of $R 2 P$. The role of NATO forces was explicitly for the protection of the Libyans and for the avoidance of public massacres. However, the role of the NATO forces was not to instigate regime change. The international community was reluctant at the outbreak of the uprising to declare a unified stance; however, when rebels' control of several cities including Benghazi was at stake,

\footnotetext{
${ }^{3}$ Implementing the responsibility to protect: report of the Secretary General. UN General Assembly, 12 January 2009 A/63/677, retrieved from www.unhcr.org/refworld/docid/4989924d2.html
} 
NATO's intervention led by United States from behind took the role of protecting Libyans and ousting Qaddafi. Moreover, Qaddafi had left himself with few if no foes to defend him, so when the Arab League called for the support of the Libyan protestors, NATO forces knew that it were the right time to free the Libyans from the grip of Qaddafi.

\section{6- Intervention Against the Colonel}

What explains authoritarian regime breakdown in a case like Libya? Acknowledging that both the institutional framework and historical legacy are important, they nevertheless do not overshadow the role of external dynamics during the Arab Spring. When analyzing domestic variables, the loss of the necessities and requirements that led to the regime's establishment will lead to cracks in the regime (Przeworski in O'Donnell, Schmitter, and Whitehead 1986). Nevertheless, a tipping point affecting regime's maintenance is foreign intervention, which can occur directly or indirectly. In the case of Libya, the regime lost its legitimacy, a few members of Qaddafi's inner circle defected, and foreign pressure was exerted in terms of military assistance to the opposition.

In theoretical and comparative analyses of democratization, there are basically two major yet general paths for the breakdown of authoritarian regimes and transition towards democratization. The first path of regime breakdown is initiated from within the ruling coalition, while the second path "can be drawn from the civilianized political leadership, the military-as-government, or the military-as-institution which acts against the military-as-government or the civilianized political leadership" (Stepan in O’Donnell, Schmitter, \& Whitehead 1986: 65). Nevertheless, a society-led regime breakdown is pivotal in setting the frame for democratic transitions (Stepan in 
O’Donnell, Schmitter, \& Whitehead 1986). In the case of Libya, a society led regime breakdown with foreign pressure and military assistance led to the demise of Qaddafi's authoritarian regime.

Consequently, following the breakdown of any authoritarian regime, aspirations for democratic transitions prevail. Nevertheless, the path for democratic process and its stability depends on various contexts because "before a democratic transition can begin there must be a political community receptive to democratic aspirations. After the regime change has taken place, the same community must respond to the new possibilities for political participation" (Whitehead 2002: 65). Nevertheless, as much as it is important to pin down both the role of Libya's strategic geographic location in North Africa as a gate to the Arab, African, and Mediterranean worlds and the factor of oil wealth that allowed Qaddafi to free Libya from the economic and monetary aid of foreign powers, "the international context is a notoriously difficult variable to pin down" (Schmitter in Whitehead 1996: 28). As Schmitter notes, the role of external variables was very important in transitions in Eastern Europe, he asks: "Would the astonishingly rapid changes in Poland, Hungary, East Germany, Czechoslovakia, Romania, and Bulgaria in 1989-90 have even been imaginable, much less gone as far as they did, without a prior change in the hegemonic pretensions of the Soviet Union?" (Schmitter in Whitehead 1996: 27).

\section{7- An Unfolded Chapter}

When the waves of the Arab Spring spread gradually across the Middle East, many policy specialists attempted to analyze the time and context that led to the massive social discontent. The revolts that occurred in Tunisia, Egypt, and Libya were remarkable in the way the barriers of fear were shattered. People all around the world 
witnessed how the authoritarian regimes' coercive apparatus did not survive people's power. Nevertheless, the more authoritarian regimes used force, the larger the number of protestors became, and the more defiant people were. In the case of Libya, Qaddafi, "the prophet of the desert, was not [as] invincible as he thought" (Pargeter 2012: 163). The reason the support of foreign powers was successful in breaking Qaddafi's regime is because “domestic prodemocracy groups [were] powerful enough to constitute a credible alternative to the status-quo" (Sayyid in Schlumberger 2007: 216).

As a matter of fact, Qaddafi did not focus much on internal development as much as he focused on avenging the international community in particular the United States. Qaddafi who had "skillfully blended the threads of nationalism, antiimperialism, and pan-Islamic loyalties, which had emerged in Libya at the beginning of the twentieth century, with contemporary movements for Arab nationalism, Arab socialism, and Arab unity" (St. John 2002: 4) could not free himself from the influences of the forces of the Libyan past. Qaddafi's motive was to challenge American interests in Middle East, in Western Europe, and in all around the world (Laham 2007). With the end of the Cold War, the international community headed by the United States was determined to remove Qaddafi's regime. Libya, for all what it stands for in terms of its strategic geopolitical and natural resources, was ruled by an irritant and unpredictable dictator. However, even the period of Libyan-West détente in 2003 as a consequence of Libya's abandonment of weapons of mass destruction did not lead for better relations between the West and Qaddafi. Nevertheless, with the 2001 war on Afghanistan and the 2003 confrontation with Iraq, the several subliminal attempts to remove Qaddafi were to no avail until the Jamahiriya decided to revolt defiantly against its oppressor. 
Despite the fact that Libyan oil wealth reduced the country's dependency on foreign aid and economic assistance, "but [it] increased the complexity of [...Libya's] socioeconomic and political problems" (St. John 2002: 3). Now that Qaddafi's era has ended, witnessing a democratic transition in Libya after witnessing a regime change remains a possible scenario since "just as the audience needs the performance in order to absorb the drama, so also the citizens need a visible transition in order to internalize changed rules of political action" (Whitehead 2002: 45).

Looking at Libya after a year from the revolution, many have argued that "Libya was fast beginning to look like a collective of city states, and the periphery was taking its revenge on the center" (St. John 2002: 248). With national elections held in July 2012, the Centrist party led by the defected former economic advisor of Qaddafi, Mahmoud Jibril, heads the largest seats in the General National Congress of Libya. With no new constitution formulated and tribes maintaining security in a form of complete lawlessness, question marks are raised about the possibility of Libya's unity and cohesion after two years from the revolution. Nevertheless, it is worth mentioning that "[ousting] an authoritarian regime can swiftly degenerate into civil war if contending factions within society cannot agree on a new set of rules of the game" (Grand in Pollack et al. 2011: 25).

Moreover, examining the role of external dynamics of democratization and taking a glimpse at Whitehead's three categories for the role of international factors contagion, control, and consent - can be adopted in the case of Libya as a sequence for the processes that occurred. For the demise of Qaddafi, Libya's geostrategic location, natural resources, and the calculations of the dominant powers were important in linking international variables to national politics. 


\section{8- Conclusion}

In the mid-1970s, no one believed that countries such as East Timor, South Africa, Cambodia, and Albania would experience democratization. Whitehead notes that, "over the past twenty years, the reality of democratization has been diffused across the globe penetrating into the most remote and improbable of locations" (Whitehead 2002: 1). The Middle East, with its geographic range from Tehran to Rabat, experienced for the first time a phenomena of extended political, economic, and security crisis that began spreading across Arab countries gradually at the end of 2010. However, many authoritarian regimes in the Middle East continue to survive despite the Arab upheavals. The pattern of using coercive action against protestors was seen in almost all the states that witnessed social uprising such as Tunisia, Egypt, Bahrain, Libya, and Syria. Therefore, violence against protestors was used as a form of instigating fear among civilians to preserve the regime because "the only lesson authoritarian bureaucrats draw from past failures is that some additional repression is needed until things get straightened out" (Przeworski in O'Donnell, Schmitter, \& Whitehead 1986: 59). The importance of the Arab discontent phenomena lies not only in analyzing the causes and reasons for the Arab Spring but rather in searching for exits so that stability and prosperity can flourish in the countries that witnessed uprisings.

This chapter highlighted the strategic importance of Libya as a strategic gateway in North Africa whilst depicting the complex forty-two year rule of Qaddafi. Emphasizing the terms and the circumstances that led to NATO's modest impetus, which led to a regime change in Libya, this chapter concluded that there are multicausal variables at stake in the case of Libya. From Libya's geostrategic location, to its natural resources, and Qaddafi's idiosyncratic calculations, NATO's intervention 
was enigmatically the key for regime breakdown. The next chapter tackles the case of Bahrain. It assesses how the regional intervention led by the Gulf Cooperation Council against the protestors led to regime stability and maintenance. 


\section{CHAPTER FOUR}

\section{FROM A SHORT LIVED UPRISING TO AN}

\section{UNFINISHED REVOLUTION}

"The masses never revolt of their own accord, and they never revolt merely because they are oppressed. Indeed, so long as they are not permitted to have standards of comparison, they never even become aware that they are oppressed"- George Orwell

\section{1- Introduction}

The aftermath of even the most popular revolutions has not always been rosy. The French experienced the Great Terror after the Liberty, Equality, Fraternity revolution of 1792, the Russians became prisoners of Joseph Stalin's Great Purge after the 1917 Bolshevik revolution, and the Iranians were led by an autocratic rule after their 1979 revolt (Bradley 2012). Inspired by the Tunisian and Egyptian uprising, the Bahrainis took to the streets of Manama demanding reforms. With the eyes of the world focused on events in Tunisia, Egypt, and Libya, the social uprising in Manama had minimal media coverage. Within less than a month, autocratic regimes like that of Ben Ali and Mubarak were toppled. Arabs across the Middle East saw that regimes that were once depicted as impregnable were in fact paralyzed. Although social uprisings did not fly across all of North Africa, "the successful example of one country's transition establishes it as a model to imitate and, once a given region is sufficiently saturated with this mode of political dominance, pressure will mount to compel the remaining autocracies to conform to the newly established norm" (Whitehead 1996, p. 38). From North Africa, the wave of Arab discontent reached the shores of the Persian Gulf. Pollack argues, "in Bahrain, for instance, the 
protests immediately engaged the country's deep Sunni-Shi'i divide, to the point where it became unclear how much the new opposition was merely the old Shii opposition in a new garb and how much a different, more ecumenical protest movement (one driven more by class grievances) that embraced a wider spectrum of the Bahraini populace" was emerging (Pollack et al. 2011: 4).

This chapter analyzes the uprising that occurred in the Kingdom of Bahrain starting on 14 February 2011. It explores the role of external dynamics, international and regional, in authoritarian regime maintenance. Whilst introducing the global importance of the Arabian Peninsula, this chapter examines the international and regional reactions towards the Bahraini discontent. After explaining the reason for the lingered tension between Gulf Cooperation Council and Iran, the chapter offers explanations for the maintenance of al-Khalifa regime.

\section{2- $\quad$ The Precious Gulf}

"You cannot destroy the Polish national-consciousness or Poles on the battlefield, but if you give them power, they will destroy themselves"

\section{-Otto Eduard Leopold, Prince of Bismarck Founder and $1^{\text {st }}$ Chancellor of German Empire}

For the past two decades, vast literature has examined the unfound prerequisites in the Middle East whilst offering remedies for the existing problems. Policy makers and specialists have argued that "the specific type of non-democratic rule still dominating in the Arab world is neo-patrimonialism in which political power rests primarily on co-option" (Albrecht and Schlumberger 2004: 372). However, Brynen, Moore, Salloukh, \& Zahar argue that "neo-patrimonial strategies of cooptation and the coercive agencies physical and symbolic power failed to prevent the 
emergence of the kind of collective action that overwhelmed the state' ability to control it" (2012: 290). Moreover, the accumulation of grievances kindled the spark for "the events that began in Tunisia in January 2011 and spread to Egypt and then Libya, Jordan, Morocco, Bahrain, Syria, and beyond, [which] shook the political, social, and intellectual foundations of the Middle East" (Pollack et al. 2011: 1). The reason behind the collapse of the walls of fear across the region is because "suddenly, Arabs everywhere saw people just like themselves, angry about problems just like their own, defying vast autocracies just like those they lived under, and toppling regimes that had once seemed impregnable" (Pollack et al. 2011: 3). After all, the theories of democratic pre-requisites and the lack of democratic foundations in the Middle East have been proven falsifiable after the Arab Spring because "Arabs are not, of course, somehow genetically or culturally incapable of embracing representative democracy" (Bradley 2012: 15).

Considered a newly independent state, only forty-two years ago, Bahrain declared its independence after ending its British protectorate status. After liberating the island from Persian rule in 1783, it is worth mentioning that "for the al-Khalifa family that has ruled Bahrain for over 200 years, the notion of sharing power with the Shi'i population raises existential fears that will have to be addressed" (Doran and Shaikh in Pollack et al. 2011: 194). With several disrupted uprisings against alKhalifa's regime in 1981 and 1994-2000, the Iranians were constantly blamed for inflaming discontents in the Kingdom. Accusing Iran for all the problems that face the Bahrainis goes back to 1957 , when Bahrain was claimed by Iran to be its $14^{\text {th }}$ province; a dispute that was only resolved after the intervention of the United Nations Security Council. After the 2000 uprising, the National Action Charter was considered an embedment of promised reforms. The Charter introduced elections, 
women's right to vote, and Bahrain's Kingdom status. But reform was only promised and was never attempted. For example, the Prime Minister is Sheikh Khalifa Bin Salman Al Khalifa, the King's uncle, who has served in his position since 1971.

Nevertheless, the short-lived uprising of 2011 in Manama's Pearl Square was interpreted in different contexts because "in the foreshadowing of how external actors would respond in 2011, fears over Shiite political power accompanied Bahrain's political turmoil of the period" (Brynen, Moore, Salloukh, \& Zahar 2012: 81). The explanation behind the Bahraini political mayhem is offered "[by] the ruling alKhalifa family and its supporters in the Gulf Cooperation Council (GCC), particularly Saudi Arabia, [...as] the latest attempt by Iran to meddle in the Kingdom's internal affairs where the majority of Bahrainis are Shi'i" (Doran and Shaikh in Pollack et al. 2011: 188). Demanding political reform since 1981, demonstrations and the call up for change are not new phenomena in Bahrain.

\section{3- Challenged Interests}

Michael Doran and Salman Shaikh argue that "the crisis that flared up in Bahrain in February 2011 and the government's subsequent crackdown the following month have presented challenges for the United States regarding its interests in the Gulf' (Doran and Shaikh in Pollack et al. 2011: 188). Superseding other oil rich countries in discovering their natural resources, Bahrain's oil was discovered in 1932. Acknowledging that two issues have determined the supply and demand of the Middle Eastern oil, the U.S.-Soviet rivalry during Cold war and the Arab-Israeli conflict, "the combination of American economic, strategic, and political interests in the Gulf region has made it one of the highest priorities of American foreign policy, in both the Cold War and post-Cold war periods" (Gause 2004: 3). 
Nevertheless, it was only after the end of the Gulf war that "a new period of intense and unprecedented cooperation between the United States and the GCC countries" (Gause 2004: 40) was ushered in. It is worth noting that since the end of the Vietnam War, the American military commitment in Kuwait in 1988 was the largest direct American intervention (Gause 2004). Viewed as the stabilizer of the Gulf, it is no coincidence that "the key to American policy toward the Gulf states for more than 50 years has been their mutual interest in the production of oil and the supply of oil to the world market at prices that are acceptable for both producers and consumers" (Gause 2004: 120).

Knowing that the Caspian Basin and the Russian Federation cannot act as replacements to Gulf oil, "American oil companies were present in most of the Gulf states before official American diplomatic representatives were" (Gause 2004: 120). Walid Khadduri argues that "by 2020 it is estimated that world demand for petroleum will increase by 30 to 40 million barrels a day, with most of that demand increase coming from developing states. Two thirds of that new demand will have to be met from the Middle East" (Gause 2004: 64). Until such time that a viable alternative to oil is developed, and at affordable prices, the U.S. will remain engaged in the GCC's security concerns (Luciani 2013).

Whilst keeping a distantly friendly relationship with its non-democratic allies in the Gulf, the United States' relations with Israel have complicated the oil-security formula that it tried to balance. Both Qatar and Bahrain were honored by the status of a major non-NATO ally; however, upon the events of 2011 "much like the Sunni monarchs, Washington seem[ed] frozen by fear of change rather than giving serious attention to protestors' demands" (Brynen, Moore, Salloukh, \& Zahar 2012: 89). Moreover, claiming fulfillment of the quest for international stability and security, 
"[Obama] backed the Saudis in their invasion of Bahrain, backed Al Qaeda linked rebels in Libya, and backed the Saudi counter-revolution more generally throughout the region that relied on the support of the Muslim Brotherhood, its affiliates, and even more extremist Salafi groups from Tunisia to Egypt, Yemen to Syria” (Bradley 2012: 203).

Depicting the importance of Gulf oil markets in the Middle East, Bogdan Szajkowski argues that "the EU, for its part, is the third largest destination for Gulf exports, after Japan and the countries of South East Asia. Oil and refined petroleum by-products constitute approximately $90 \%$ of overall GCC exports to the EU" (Koch 2005: 36). Furthermore, Koch adds:

While GCC-EU relations are multi-faceted and multi-dimensional in character, the overall ineffectiveness and to some degree disappointment cannot be denied. Simply stated, up to this point the relationship has not progressed sufficiently for both sides to realize the full potential of interregional cooperation or to serve as the strategic rationale for mutually beneficial cooperation. In particular as far as development over the past years is concerned, the current status of GCC-EU relations stands in contrast to the historical, geopolitical, and strategic considerations and interdependence that should lie at the heart of the relationship (Koch 2005: 8).

Based on the geostrategic and oil interests of the United States and the EU in the Gulf, it is worth noting that the 2011 uprisings crippled the reaction of the international community. The reason behind the doubled international apprehension is fear of change versus fear of disrupting relations with the "precious" Gulf. As Table 4.1 shows, Qatar presides atop the richest countries in the world according to GDP purchasing power parity per capita while the other five GCC countries are among the top 40 richest countries of the world. Fearing Persian influence in the Middle East, a set of complicated variables lie in the analysis of the importance of the relation between GCC and the international community, in particular, the United States. Nevertheless, when the social uprising in Manama occurred on February $14^{\text {th }}$, the 
reason why the United States might not have taken an active role in crippling the

Bahraini protestors was to rather allow the GCC to take appropriate action.

Table 4.1- Richest Countries in the World as of $2012^{4}$

\begin{tabular}{|c|c|c|c|c|c|}
\hline Rank & Country & $\begin{array}{l}\text { GDP PPP per } \\
\text { Capita }\end{array}$ & Rank & Country & $\begin{array}{l}\text { GDP PPP } \\
\text { per Capita }\end{array}$ \\
\hline 1 & Qatar & $\$ 106,283.96$ & 21 & Denmark & $\$ 37,713.42$ \\
\hline 2 & Luxembourg & $\$ 79,649.49$ & 22 & Finland & $\$ 36,736.33$ \\
\hline 3 & Singapore & $\$ 61,046.96$ & 23 & $\begin{array}{l}\text { United } \\
\text { Kingdom }\end{array}$ & $\$ 36,605.02$ \\
\hline 4 & Norway & $\$ 54,479.06$ & 24 & Japan & $\$ 36,040.14$ \\
\hline 5 & Hong Kong SAR & $\$ 50,716.14$ & 25 & France & $\$ 35,613.45$ \\
\hline 6 & $\begin{array}{l}\text { Brunei } \\
\text { Darussalam }\end{array}$ & $\$ 50,440.03$ & 26 & South Korea & $\$ 33,171.53$ \\
\hline 7 & United States & $\$ 49,601.41$ & 27 & The Bahamas & $\$ 31,784.15$ \\
\hline 8 & $\begin{array}{l}\text { United Arab } \\
\text { Emirates }\end{array}$ & $\$ 48,434.60$ & 28 & Israel & $\$ 31,514.88$ \\
\hline 9 & Switzerland & $\$ 44,015.97$ & 29 & Spain & $\$ 30,315.48$ \\
\hline 10 & Kuwait & $\$ 43,773.88$ & 30 & Italy & $\$ 30,132.59$ \\
\hline 11 & Austria & $\$ 42,589.72$ & 31 & Slovenia & $\$ 28,704.93$ \\
\hline 12 & Netherlands & $\$ 42,319.57$ & 32 & Cyprus & $\$ 28,645.62$ \\
\hline 13 & Australia & $\$ 41,467.65$ & 33 & New Zealand & $\$ 28,372.27$ \\
\hline 14 & Canada & $\$ 41,335.06$ & 34 & Bahrain & $\$ 27,907.52$ \\
\hline 15 & Sweden & $\$ 41,129.94$ & 35 & $\begin{array}{l}\text { Czech } \\
\text { Republic }\end{array}$ & $\$ 27,380.56$ \\
\hline 16 & Ireland & $\$ 40,443.26$ & 36 & Oman & $\$ 27,349.80$ \\
\hline 17 & $\begin{array}{l}\text { Taiwan Province } \\
\text { of China }\end{array}$ & $\$ 39,217.78$ & 37 & Malta & $\$ 25,874.89$ \\
\hline 18 & Iceland & $\$ 39,082.93$ & 38 & Saudi Arabia & $\$ 25,465.98$ \\
\hline 19 & Germany & $\$ 38,695.94$ & 39 & Seychelles & $\$ 25,439.92$ \\
\hline 20 & Belgium & $\$ 37,995.23$ & 40 & Greece & $\$ 25,343.24$ \\
\hline
\end{tabular}

\footnotetext{
${ }^{4}$ The Richest Countries in the world according to GDP purchasing power parity per capita. Retrieved from Global Finance (2012), http://www.gfmag.com/tools/global-database/economic-data/
} 


\section{4- The New Manifestation}

The reaction of the GCC countries to the social uprising in Tunisia, Egypt, Libya, Yemen, Syria, and Bahrain varied. It "has been a mix of economic handouts, use of patronage, limited political and economic reforms as well as domestic repression and even military intervention" (Colombo 2012: 2). The reason for the varied responses can be attributed to different variables such as the geographical location of the countries experiencing uprising, the nature of the regime, and geopolitical interests of international community with the country concerned.

The GCC's response towards the countries that witnessed uprisings can be divided into two categories: countries outside the Gulf region and countries in the Gulf region. Nevertheless, there was also a clear-cut difference between all GCC countries on one hand and Qatar on the other. But there was no differing response between GCC members in the case of Bahrain. It is no hidden secret that since the accession of Sheikh Hamad Bin Khalifa Al Thani to power in 1995, Qatar has aimed at assuming a regional hegemonic role. In the case of Tunisia, Saudi Arabia, with all what the Kingdom represents in the GCC, stepped to grant asylum for the twentythree years rulers of Tunisia, Ben Ali and his kin. As for Egypt, the GCC countries called for stability and peace whilst offering support for Mubarak. Despite the support for the Ben Ali and Mubarak regimes, the "GCC partners, [along with] Saudi Arabia is now supporting certain political forces e.g., the Islamists that have gained power in Tunisia and in Egypt, with a view to maintain a favorable sectarian balance" (Colombo 2012: 12). As for the case of Yemen, a country in the Arabian Peninsula with the hope of becoming a member of the GCC, there was a call for the ousting of Ali Abdallah Saleh to avoid a Yemeni civil war. A civil war in Yemen could have major repercussions on the GCC states especially Saudi Arabia. Therefore, the 
decision in Yemen was the removal of the head of state, Saleh, whilst ensuring regime maintenance. Nevertheless, the proactive role of Saudi Arabia in the countries which witnessed social unrest can be best described in the words of Brynen, Moore, Salloukh, \& Zahar:

Riyadh emerged as the Mecca of political asylums, providing refuge for Tunisia's Ben Ali and Yemen's Saleh. It pressured the United States not to let go of Mubarak, flexed its financial power to shield him from a humiliating debacle, and when all else failed it switched to a co-optation strategy to buy influence in Egypt's new order. Similarly, it has scrambled to reorder the political deck in a manner that protects its political influence in a post-Saleh Yemen. Moreover, and in a move aimed at shielding nonoil monarchical regimes from the wave of popular uprisings, it led the drive to inject Bahrain and Oman with funds to buy political acquiescence (2012: 296).

On the other hand, only in the cases of Libya and Syria did the GCC countries make the decision to support the rebellious movements. Supporting the rebellious movements in Libya a bit further than the other GCC countries, Qatar was the first Arab country to recognize the Libyan National Transitional Council. Sheikh Al Thani did not stop there; rather he made a decision as a major non-NATO ally to send around six fighter jets to Libya as a sign of support for NATO's intervention (Roberts 2011). Nevertheless, Doha's financial and military support for the Libyan rebels can be best described as an attempt "to occupy regional leadership role Saudi Arabia abandoned in Libya to reserve for itself a privileged place in the good books of the United States" (Brynen, Moore, Salloukh, \& Zahar 2012: 296). From a mobilized political and military action against the Colonel, the Emir launched the war of media against Qaddafi. Therefore, "to this end, Qatar, skillfully exploited Al Jazeera, the satellite broadcast based in Doha to rally the Arab public opinion in favor of the foreign intervention in Libya and of its own role as a key Arab player, a role commensurate to its wealth and clout" (Colombo 2012: 7). Similarly, in the case of Syria, the GCC states support till this day the Syrian aspirations for ousting Al-Assad. 
Pleading support for the Syrian protestors' demands to gain freedom, the GCC states recognized the Syrian National Council. Therefore, Qatar has publicly condemned the “regime's [Syrian] bloody clampdown" against protestors and supported the armed revolt (Brynen, Moore, Salloukh, Zahar 2012: 296) whereas Saudi Arabia's support for the Syrian rebellion "is governed by similar geopolitical calculations, intended to force regime change in Damascus to compensate for Riyadh's loss of post- Saddam Iraq to Iran" (2012: 297).

Table 4.2- Deaths in the Arab Awakening ${ }^{5}$

Deaths in the Arab awakening

Recorded deaths during protests/clashes between civilians and government security forces

To July 12 th 2011 (Libyan figures unavailable)

\begin{tabular}{|c|c|c|c|c|c|}
\hline Country & Status & Population, $\mathrm{m}^{\star}$ & $\begin{array}{l}\text { Number killed, } \\
\text { minimum }\end{array}$ & $\begin{array}{l}\text { Deaths per } \\
\text { m population }\end{array}$ & Period of unrest \\
\hline Syria & Ongoing revolution & 20.4 & $1,300^{\dagger}$ & 63.7 & Mar 2011 - present \\
\hline Egypt & Regime toppled & 81.8 & 846 & 10.4 & Jan - Feb 2011 \\
\hline Tunisia & Regime toppled & 10.5 & $219 \ddagger$ & 20.9 & Dec 2010 - Jan 2011 \\
\hline Yemen & Ongoing revolution & 24.1 & $200 \$$ & 8.3 & Feb 2011 - present \\
\hline Bahrain & Uprising crushed & 1.3 & $29 * *$ & 23.0 & Feb - Jun 2011 \\
\hline
\end{tabular}

Doran and Shaikh argue that "although riots and demonstrations have not been uncommon since the 1980s, Bahrain has entered a new era of instability fueled by a combination of long-standing grievances, the competition of regional powers, and transformative aspirations" (Doran and Shaikh in Pollack et al. 2011: 188). Therefore, when social uprisings erupted in the Persian Gulf in 2011, in Bahrain, fears of a growing Bahraini Shiite-Iranian crescent of support mounted. Bahrain, along with the

\footnotetext{
5 The Economist (July 14, 2011) "Price of Protest, so Far". Retrieved from http://www.economist.com/blogs/dailychart/2011/07/arab-spring-death-toll
} 
five countries that witnessed social unrest, has been listed as one of the countries with high death totals during civilian-security clashes (refer to Table 4.2). The uprising in Manama was crushed by blood and sword. With the al-Khalifa request for help from Saudi Arabia, the Saudi intervention in Bahrain can be similarly depicted to the Soviet Union bloody squash of Hungarian protests in 1956. Therefore, the Saudi intervention cannot by all means be justified; it was not a humanitarian intervention rather it was for the maintenance of the Shiite-fearing al-Khalifa regime with a more general Arabian Peninsula fear of mounting Iranian influence. On the other hand, "while Bahrain is often depicted as a majority Shiite country ruled by a Sunni monarchy, the country's politics should not be viewed as flowing from a mere religious divide" (Brynen, Moore, Salloukh, \& Zahar 2012: 80). Accordingly, Doran and Shaikh argue that there is no if not few evidence corresponding to the contemplation of Bahraini Shiites for Persian leadership and orders (Pollack et al. 2011). In most of the Middle Eastern cases, what starts as a call for freedom and liberty usually ends up as a religious divide. Nevertheless, "the al-Khalifas' fear of Iranian hegemony and Tehran's ability to galvanize Bahrain's majority Shi'i population stem from a long-standing, and oft-deserved, suspicion of Iran” (Doran and Shaikh in Pollack et al. 2011: 191). Unlike in the case of Oman, Qatar, the United Arab Emirates, and Kuwait, the Saudi and Bahraini "Shiite communities are politically, economically, and socially marginalized and they are often portrayed by the government as a threat to social cohesion and national stability" (Colombo 2012: $11)$.

The Gulf Cooperation Council was formed in 1981 with the purpose of establishing political and economic cooperation among the Gulf States. Nevertheless, with mounting security fears in 1984, the Peninsula Shield Force of the GCC was 
formed. The only intervention made by the Peninsula Shield Force against an external threat was in 1990-1991 when the Iraqi-Kuwaiti war occurred. Nevertheless, it is worth noting that “always fearful of Iran's regional ascendancy, GCC countries have grown increasingly uncomfortable with the Islamic Republic's outreach and influence after the United States' toppling of the Taliban in Afghanistan and Saddam Hussein in Iraq" (Colombo 2012: 2). However, it was in 2011 that the Peninsula Shield Force, stationed in Saudi Arabia, made its first intervention in the internal affairs of a Gulf state for the maintenance of peace. Upon the request of the al-Khalifa monarchy of Bahrain, the Shield Force crossed King Fahd Causeway, a concrete connection that connects Bahrain to Saudi Arabia, for the rescue of the Sunni ruling family of Bahrain. Therefore, between fears of regime change in a Gulf monarchy and the spread of Iranian influence, “Saudi Arabia’s fear of Iran's growing geopolitical power played an instrumental role in the former's military intervention in Bahrain and the consequent annihilation of a genuinely cross-sectarian democratic movement demanding the establishment of a constitutional monarchy to replace minority Sunni rule" (Brynen, Moore, Salloukh, \& Zahar 2012: 297).

\section{5- $\quad$ Lingering Tension}

"If Bahrain is supposed to be integrated into another country, it must be Iran and not Saudi Arabia." -Ali Larijani, Iranian Parliament Speaker - May 2012

Weighing regime stability over populist aspirations, "the Arab world's geostrategic location and its place in the global capitalist economy have long played in favor of authoritarian regimes" (Brynen, Moore, Salloukh, \& Zahar 2012: 297). The maintenance of the oil-rich Gulf regime in Bahrain was viewed as crucial for the 
avoidance of a wave of populist discontent across the Gulf countries. Taking the lead in defending the ruling family of Bahrain, "Saudi Arabia's strong advocacy for the use of GCC forces in Bahrain, [has allowed] many [to] see Riyadh as a counterrevolutionary agent in the Bahraini context and more broadly in the Arab Spring" (Pollack et al. 2011: 192).

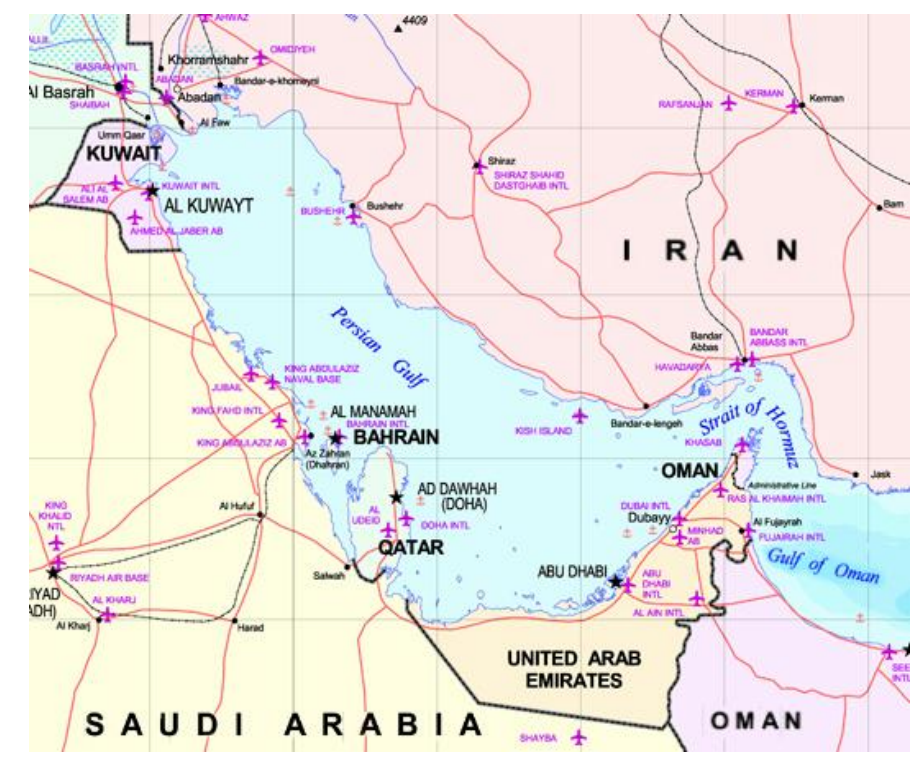

Figure 4.1- Map of the Persian Gulf ${ }^{6}$

With a presence in the Gulf since World War two, "the American military has served as the main guarantor of Bahrain's security at least since the two countries signed a Defense Cooperation Agreement in 1991, and [arguably] well before" (Doran and Shaikh in Pollack et al. 2011: 193). Home for the U.S. Naval forces since 1947, "Bahrain [...] provides the head-quarters for the U.S. Navy's Fifth fleet, responsible for defending the Gulf, the Red Sea, the Arabian Sea, and the East coast of Africa" (Doran and Shaikh in Pollack et al. 2011: 194). Despite the strategic importance of Bahrain to the United States, "the tactics of American policy in the Gulf region have varied over time, shifting with changes in the world strategic picture

\footnotetext{
${ }^{6}$ Map retrieved from Pars Times, www.parstimes.com/persian-gulf
} 
and with changes in the regional politics of the Middle East and the Gulf region" (Gause 2004: 120). Nevertheless, Gause argues that "American liberals have always been wary of the strong U.S.-Saudi relationship, as part of their general suspicion of U.S. allies who are undemocratic and do not meet American standards on human rights and women's rights" (2004: 72). Therefore, the United States and the European Union have maintained friendly relations with the Gulf in order to maintain the continuous flow of geopolitical and economic interests; however, their relationship falls within the category of friends with shared interests yet with a maintained distance. The reaction of the international community to the uprising in Manama proved that "the prompt repression of the Bahraini revolt and the GCC's activism on other Arab Spring fronts such as Libya and Syria has freed the West from the incumbency to have to intervene in the Gulf, jeopardizing its well established relations with the Gulf regimes" (Colombo 2012: 13)

Within a month of the start of the uprising in Bahrain, the Saudi intervention stifled "a harsh sectarian crackdown against protestors in Bahrain [which] risked sparking a new regional proxy war between Saudi Arabia and Iran" (Lynch 2012: 9). To date, due to the "lack [... of $]$ a shared understanding of the region's strategic outlook, latent tensions between the GCC and Iran have persisted" and will continue to linger (Colombo 2012: 11).

With Iran placed on the list of the axis of evil in Washington, the United States could not jeopardize its relations with its Gulf allies through a direct military intervention because "as oil market remains an integrated world market, production and pricing decisions in the Gulf States would directly affect oil for all customers around the world" (Gause 2004: 65). On the other hand, Saudi Arabia, which is connected to Bahrain not only through the Causeway but also through royal 
marriages, could not risk having a successful regime change in a Gulf monarchy in fear of a domino effect and of an Iranian expanded influence. The post-Arab Spring Iranian influence across the Middle East has been seen evident in the improvement of Tehran's relations with the post-Mubarak regime in Egypt (Colombo 2012). Therefore, once again, the geopolitical and security interests have superseded the aspirations of reform for the sake of regime stability and maintenance.

\section{6- Conclusion}

Security and oil remains the bond that keeps GCC-US relations vibrant. Nevertheless, what Gause argued for eight years ago remains valid because "the core of the relationship between the United States and the GCC states remain oil, and the centrality of the Gulf to the future energy needs of both the United States and the world as a whole will continue to keep the US-GCC relationship at the top of the American agenda" (Gause 2004: 64). Therefore, energy security will remain a vital aspect of U.S. strategy in the Middle East (Luciani 2013). If there is a failure of the Arab Spring then, "to date, the greatest failure of the Arab Spring is Bahrain" (Colombo 2012: 13).

Just as Libya acts as an important and strategic gateway in North Africa, we cannot ignore the fact that taking a look ahead, "the future of the Arab world may hinge on this Island [Bahrain] whose prospects today are bleak and whose small size conceals its importance to broader regional and global balances" (Colombo 2012: 13).

This chapter argued that the GCC under the auspices of Saudi Arabia, intervened on March $14^{\text {th }}$, a month after the eruption of the social uprising in Bahrain for two main reasons. The first reason for silencing the Bahraini discontent and maintaining al-Khalifa's regime is because simply none of the Gulf regimes can 
accept a regime change in a Gulf monarchy. The need for isolating the Peninsula from the waves of Arab discontent -ensuring regime stability- was of greater importance than any democratic aspirations. The second reason had a more indirect justification and that is to crush any attempted Iranian influence in the region. Moreover, the chapter examined the United States' policy towards the Gulf. The policy has been to maintain a friendly relationship; however, a distant one with the monarchies of the Gulf. The reason is because aside from risking its relationship with the Gulf monarchies, a projected United States led-interference would have been disruptive for the country's image and would have shed lights on its relation with its non-democratic allies. Therefore, between geostrategic interests of the Gulf monarchies and the maintenance of the flow of oil, the decision was to have a direct military intervention in Bahrain guided by Saudi Arabia to protect the al-Khalifa regime.

The next chapter will conclude in a comparative and analytical approach the variations in the role of external dynamics in light of the Arab Spring in the two case studies, Libya and Bahrain. The chapter will assess the dimension and implication of the varied external response in the outcome of popular uprisings, which can result in either regime maintenance or breakdown. 


\section{CHAPTER FIVE}

\section{CONCLUSION}

"The storm of unrest that spread from the Atlantic to the Persian Gulf may have subsided, at least in some parts of the region, but its story has just begun [...] the result is that the Middle East will never be the same”- Kenneth Pollack

\section{1- Summing Up}

This thesis has assessed the important impact of external variables on political transition outcomes. In pre-Arab Spring literature, focus has been on the importance of tackling questions of authoritarian resilience and the importance of providing remedies to Middle Eastern exceptionalism with no concrete consideration for a cure. It is true that "historical precedents do shape our assumptions about current events" (Behr 2012: 13); however, after the Arab Spring, the theories of exceptionalism are refuted once and for all. An overlooked variable in the study of democratic transitions has been the role of external variables - a double-edged sword that can shift political transition towards regime maintenance or regime breakdown.

Many scholars have argued against the use of the term Spring as a depiction of the 17 December snowballed events of the Arab world. Describing the events of 2010 as "intifada", "nahda", "sahwa", and "thawra" reflected respectively as uprising, renaissance, awakening, and revolution, offers more justice to the demanded democratic aspirations of the Arab youth (Khouri 2011). The term Spring was used to describe the 1968 Czechoslovakia and the Springtime of Nations in 1848 of Europe. Unfortunately, both movements of 1968 and 1848 collapsed within a year of their attempted revolts. However, to describe events in the Middle East, the term Spring 
was used by various U.S. conservatives to describe the 2005 movements in Middle East, particularly Lebanon (Keating 2011).

With incessantly repeated terminologies in the study of the Middle East such as democracy and democratization, there are various questions to be addressed in a post-Arab Spring MENA. Is there a possibility of witnessing democracy or democratization in the Arab world? And "is it these popular struggles and the responses they trigger from local, regional, and international actors that will determine the future of authoritarianism and the potential for democracy in the Arab world?" (Brynen, Moore, Salloukh, \& Zahar 2012: 301). Has the role of external variables in democratic transitions been overlooked to the extent that it cannot be excluded from study of MENA after the Arab Spring?

This chapter will assess in a comparative approach the implications of the role of external dynamics on the outcome of social uprisings in both studied cases, Libya and Bahrain. The chapter will also explain the importance of bringing back the role of external variables in the study of democratic transitions as an important paradigm in the study of the Middle East.

\section{2- The Eschatology of the Arab Spring}

"Does Big Brother exist?

Of course he exists. The Party exists. Big Brother is the embodiment of the Party. Does he exist in the same way as I exist?

You do not exist"

- George Orwell, 1984

"At the crossroads of Europe, Asia, and Africa, the Middle East is where a big part of the world comes together" (Pollack et al. 2011: 279). Despite vast literature emphasizing the problems and impediments of Arab world democratization, "no 
academic specialist on the Middle East (of whom I am aware) predicted the timing and extent of the region-wide upheavals in the Arab world that began in December 2010 and continue to day" (Gause 2011: 11). A swift examination of the Arab Spring reveals that "[it] so far toppled some authoritarian regimes, pitted others in bloody conflicts with their societies, forced some to accommodate or co-opt popular demands, and in the process sent tremors throughout the theoretical edifice that students of Arab politics assembled to explain authoritarian persistence" (Brynen, Moore, Salloukh, \& Zahar 2012: 287). Moreover, in most cases, "it often happens that the revolutionaries who sacrificed themselves are then dismayed to see their hopes dashed while a new order that is as bad as, if not worse than, the one they ousted becomes reality" (Bradley 2012: 2). The most successful aspect of the Arab Spring is that "[it] made clear [...] that the old ways of buying the silence of the opposition through patronage and corruption might not work forever" (Colombo 2012: 13). The major challenge facing Middle Eastern regimes now is the schism between the old and the new, youth generation, who are in demand for new definitions of political leadership, economic development, and social justice. Therefore, the disenchantment between the ruler and the ruled is growing vastly in the MENA region.

It is no coincidence that the spark of the Arab Spring began from Tunisia's Sidi Bouzid as a call for dignity and freedom. In reference to Figure 5.1, the Jasmine Revolution protestors have called for Bourguiba's modern Tunisia. Nevertheless, similar to the case of Tunisia, Arab Spring protestors in other countries have used symbolic indications referring to their post-independence period as a reflection of their demand for freedom and liberation. Almost every Arab Spring protestor had a Bourguiba-like idol, symbol, or cause. Moreover, "no one could have predicted that 
the match struck by Mohammed Bouazizi to set himself afire in Sidi Bouzid on December 17, 2010, would ignite the entire Arab world, but the kindling had been laid and was there for all to see years before" (Pollack et al. 2011: 3). Nevertheless, when the events in the Middle East erupted, the international community at large stood in perplexity because "the rapid pace of internal change tends to out-run the decision-making capacity of most external actors" (Whitehead 1996, p. 40).

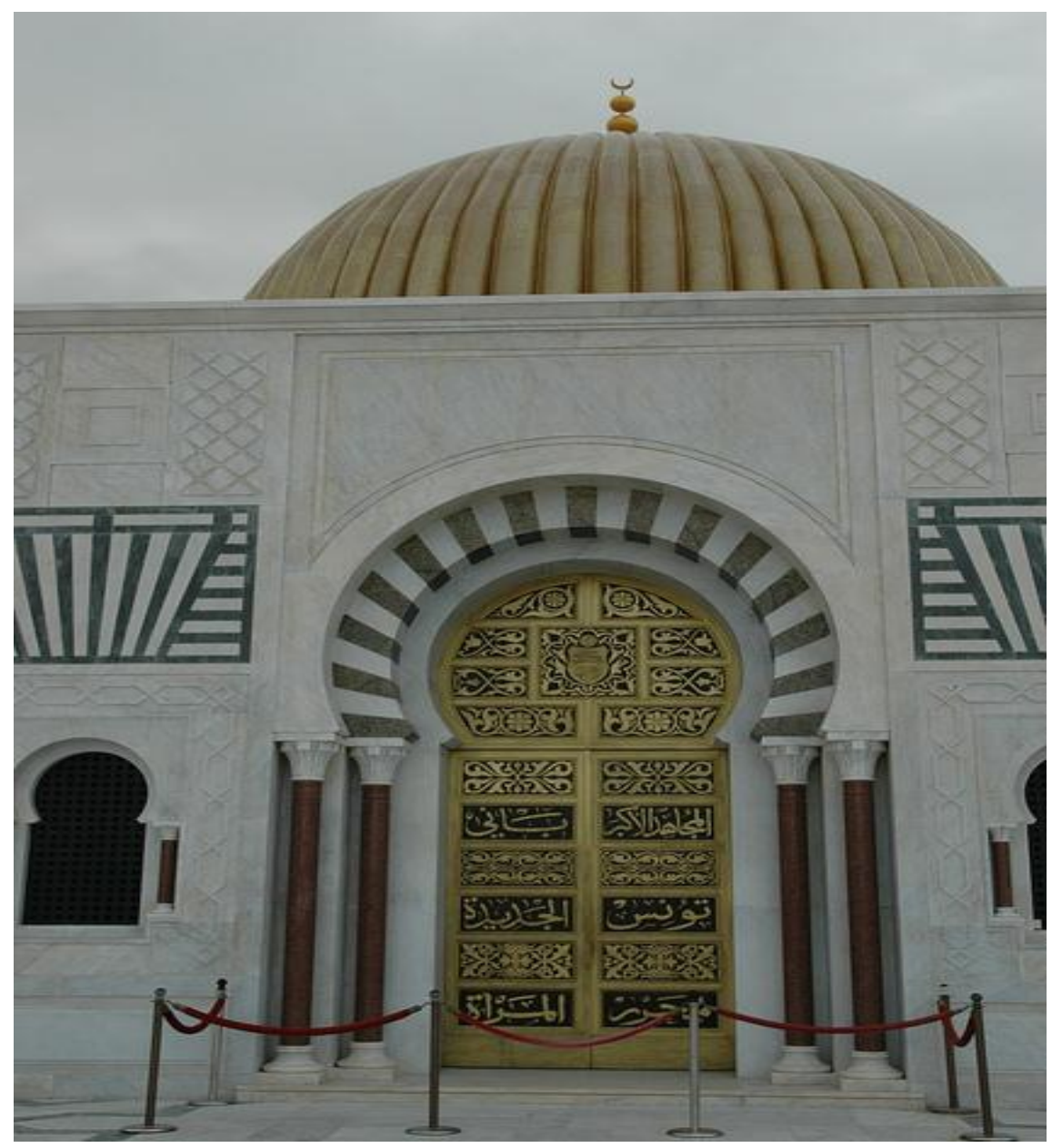

Figure 5.1- Habib Bourguiba Mausoleum in Monastir with encryptions in Arabic: "the Supreme Combatant, the Builder of Modern Tunisia, the Liberator of Women"

\footnotetext{
${ }^{7}$ As described by Abigail Hole in his 2007 book "Tunisia" and image is retrieved from www.photosvoyages.com/mausoleum-door.html
} 
Between political liberalization and aspects of democratization lies a fundamental distinction; however, the long history of examining the Middle Eastern regimes has been crammed with vast misinterpretations. The aroma of repeated elections, lessened media restrictions, and advanced social freedoms has contributed to the misinterpreted liberalizing image of the Middle East. But do all these methodical contributions enhance authoritarian regimes' legitimacy? When legitimacy is lost, the regime uses its sole technique: the usage of coercive measures to preserve itself. Nevertheless, the side on which the external coercive measures are used for support can tip the outcome either towards regime breakdown or regime preservation. It has been evident that the factor of legitimacy has been lost in all the Arab states, which witnessed social uprisings. Despite the dominated neo-patrimonial and co-optation systems of power in the Middle East, legitimacy is a crucial factor to be looked upon because “even in cases such as Castro's Cuba, Saddam's Iraq, or the Soviet Union under Stalin, there are clear indicators of political rulers trying to gain and maintain at least some measure of political legitimacy" (Albrecht and Schlumberger 2004: 372).

After the Arab Spring, the major debates have shifted towards political transitions, the outcome of social movements, and who answered the exceptional arguments of Middle Eastern authoritarianism correctly. The major arguments revolving around the resilient authoritarian regimes of the Middle East can be summarized into three key categories: Islam, oil, and repressive mechanisms. Nevertheless, the eighteen-year ago arguments of Michael Hudson and Lisa Anderson on the importance of the political cultural approach and Michael Herb's importance of family coalition have been proven falsifiable after the Arab Spring. Recent arguments have resonated with the fact that with the exception of Bahrain, the major social 
uprisings have not occurred in monarchies, the oil-rich countries of the Middle East have been capable of repressing political turmoil. What about the case of Libya? The case of Libya, an oil-rich country, is exceptional to this argument due to NATO's decisive intervention. If it were not for NATO, Qaddafi's forces would have been capable of ending the social discontent. Qaddafi followed Stalin's approach of emasculating and politicizing the military because of growing distrust of the armed forces. Forming personalized military battalions, controlled by his sons, Qaddafi was capable of holding on to power for 42 years. Nevertheless, the violent replacement of regimes is not a new theme in Arab politics. The first theorization of this common theme has been by, the Tunisian philosopher, Ibn Khaldun. With fear barriers shattered in a momentous Arab discontent, Ibn Khaldun discussed the reasons behind the up-rage of the masses some 600 years ago:

Good rulership is equivalent to mildness. If the ruler uses force and is ready to mete out punishment and eager to expose the faults of people and to count their sins, [his subjects] become fearful and depressed and seek to protect themselves against him through lies, ruses, and deceit... They often abandon [the ruler] on the battlefield and fail to support his defensive enterprises... The subjects often conspire to kill the ruler. Thus the dynasty decays, and the fence that protects it lies in ruins (Ibn Khaldun 1958: chapter VI, section 22). ${ }^{8}$

Therefore, use of coercion leads to a reciprocal reaction and when the regime losses its veil of legitimacy, the countdown of regime survival begins.

\footnotetext{
${ }^{8}$ Al Muqaddimah was initially written as part of a book in 1377.
} 


\section{3- Impact of Varied Variables}

Table 5.1- Results of Interaction between Internal and External Variables on Regime Outcome

\begin{tabular}{|c|c|c|}
\hline $\begin{array}{c}\text { Internal variable (populist } \\
\text { appeal towards regime) }\end{array}$ & External Variable & Outcome (for regime) \\
\hline Support & Oppose & Will Vary \\
\hline Oppose & Support & Survival \\
\hline Support & Support & Survival \\
\hline Oppose & Oppose & Breakdown \\
\hline
\end{tabular}

After the Arab Spring, the role of external dynamics of democratization cannot be sidelined anymore. Having the external variable as the independent variable leaves regime breakdown or maintenance as the dependent variable. The relationship between the independent and dependent variables is not uni-causal, however. Operationalizing a number of variables such as oil, geopolitical location, alliances, and foreign policy, the extent and rate of external impetus dominates the outcome. As Table 5.1 shows, the case of Libya falls into the last category of oppose-opposebreakdown. While the Libyan protestors demanded the ousting of Qaddafi along with his regime, NATO's engineered intervention under the banner of humanitarian assistance was critical to leading to regime breakdown in Libya. On the other hand, the case of Bahrain falls into the second category of oppose-support-survival. Today, modest demonstrations occur in Bahrain, whether on the second year anniversary of the uprising or couple of weeks before the start of Formula One races in Manama. Nevertheless, the regional intervention led by GCC under auspices of Saudi Arabia with a United States approval was the determinative factor in al-Khalifa's regime maintenance and survival. 
Despite the fact that "only a handful of regimes in the Middle East have so far fallen to the wave of the popular unrest that has swept the region" (Pollack et al. 2011: 141), there are four implications that can be derived as an outcome of the interaction between internal and external variables on regime outcomes. As Table 5.1 makes clear, Libya and Bahrain fall respectively within the oppose-opposebreakdown and the oppose-support-survival models. Moreover, the support-oppose scenario will need further investigation in order to determine its impact on regime outcomes. As for the support-support case, the standardized outcome is for regime survival since both variables positively reinforce regime maintenance. As argued in previous chapters, the role of external factor has a fundamental impact on the process of transition, which can lead to regime breakdown or regime maintenance. Facing a regime breakdown in Libya, the regime change experienced in post-Qaddafi era is an initial step in the process of transition. Comparing the case of Libya to other countries that witnessed conflict such as Afghanistan and Iraq, "the fall of the old regime is only the first step in a political transition" (Al Turk in Pollack et al. 2011: 121). In the case of Bahrain, the process of transition did not even begin; it faced the impeding coercive measures taken by regime with support of regional forces.

Table 5.2 provides an assessment of the implications of the Arab Spring whilst highlight the variations that can be derived from it. The major implications in relation to the Arab Spring countries can be summed in four models. In the case of Yemen, as argued in chapter four, the ousting of Ali Abdullah Saleh did not lead to a regime breakdown, but rather power was retained by the pre-uprising apparatus. As for regime breakdown, the cases of Egypt, Tunisia, and Libya fall within this category. Nevertheless, in the cases of Saudi Arabia and Kuwait, the minor uprisings that occurred were met with coercive measures taken by regime, thus uprisings were 
merely short lived. Moreover, in the case of Bahrain, the uprising was similarly crushed with assistance from the Peninsula Shield Force. As for the on-going civil war in Syria, there is yet to be a definitive outcome. To date, there is neither regime breakdown nor can it be said that there is regime survival.

Table 5.2- Assessing Implications of the Arab Spring

\begin{tabular}{|c|c|c|}
\hline \# & $\begin{array}{c}\text { Assessing Implications of the } \\
\text { Arab Spring }\end{array}$ & Arab Spring Countries \\
\hline 1 & Power is retained by pre-uprising apparatus & Yemen \\
\hline 2 & $\begin{array}{l}\text { Regime survival through repression (with/ without } \\
\text { support of international/regional forces) }\end{array}$ & Bahrain, Saudi Arabia, Kuwait \\
\hline 3 & Neither regime breakdown nor regime survival & Syria \\
\hline 4 & Regime Breakdown & Libya, Egypt, Tunisia \\
\hline
\end{tabular}

Moreover, an important aspect to be assessed after the Arab Spring is the role of the United States. Pollack argue that "while these revolutions were not made in America, American actions may have an outside impact, perhaps even on their ultimate success or failure" (Pollack et al. 2011: 1). The United States sidelined itself from a leading role whereby "open endorsement of regime change was reserved for, respectively, unpredictable and undervalued dictators such as Qaddafi or geopolitical opponents such as Syria” (Brynen, Moore, Salloukh, \& Zahar 2012: 298). Despite the fact that many have criticized the policies of the Obama administration in the wake of the Arab Spring, "yet by muddling through and insisting on keeping the United States 
on the right side of history throughout the course of the Arab revolutions, the Obama administration has ensured that the new regimes in the region will have to continue to work with the United States, and ensured that the U.S. is not diverted from its overriding strategic reorientation towards the Asia-Pacific" (Kitchen 2012: 53). In other words, the reason the United States has been cautiously sidelining itself is because "[it] has had to tread a fine line between support for its values - and what it conceives as its long term interests - represented by political reform in the region, and the protection of what it perceives as its core regional interests" (Kitchen 2012: 57). 


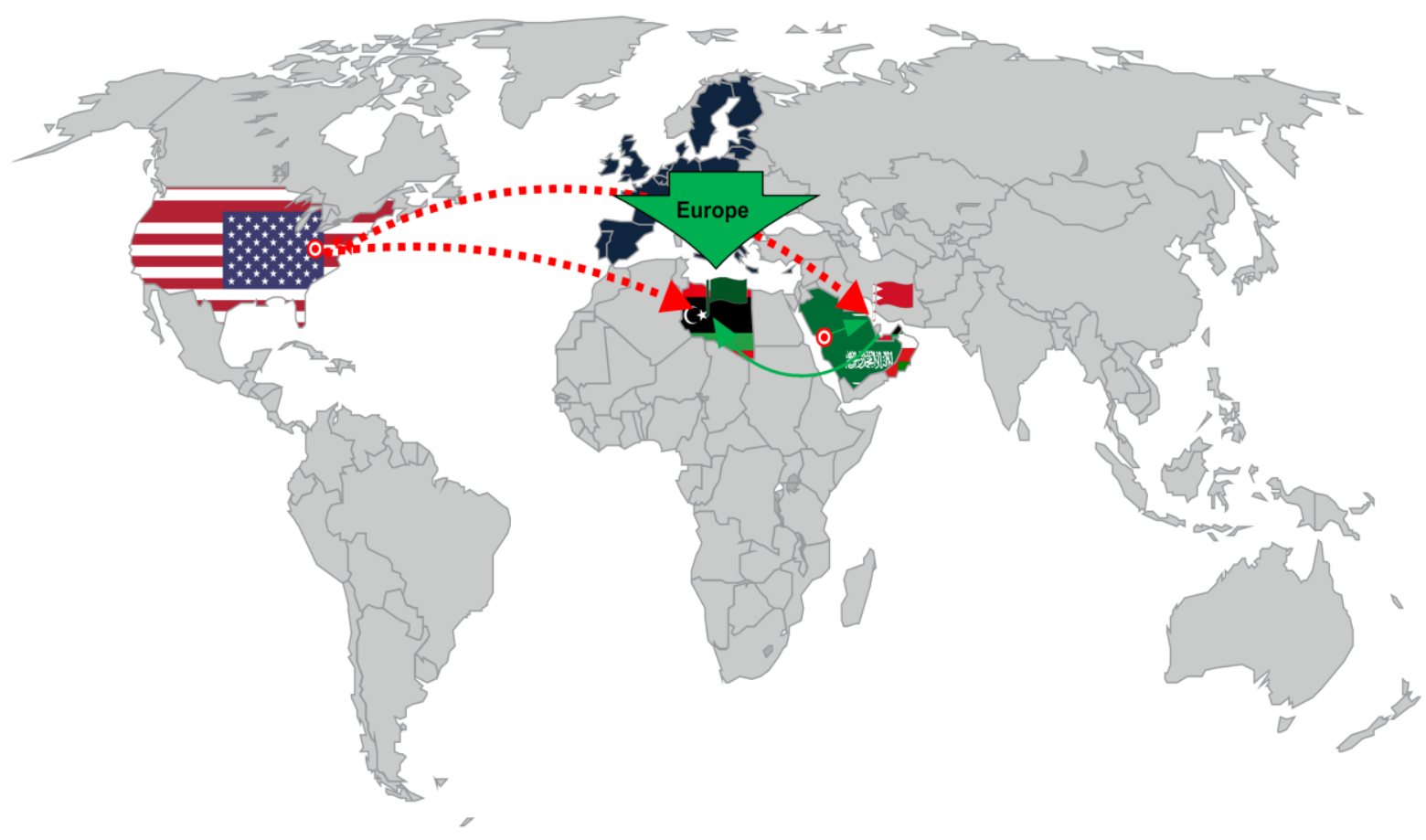

\begin{tabular}{|c|}
\hline $\begin{array}{c}\text { Military Contribution } \\
\text { in Bahrain }\end{array}$ \\
\hline GCC Countries: \\
\hline Saudi Arabia \\
\hline Kuwait \\
\hline UAE \\
\hline Qatar \\
\hline Oman \\
\hline
\end{tabular}

\begin{tabular}{|c|c|c|}
\hline \multicolumn{3}{|c|}{ Military Contribution in Libya } \\
\hline Qatar & UAE & Jordan \\
\hline Belgium & Bulgaria & Canada \\
\hline Denmark & France & Greece \\
\hline Italy & Netherlands & Norway \\
\hline Spain & Romania & Sweden \\
\hline Turkey & U.K. & U.S.A. \\
\hline
\end{tabular}

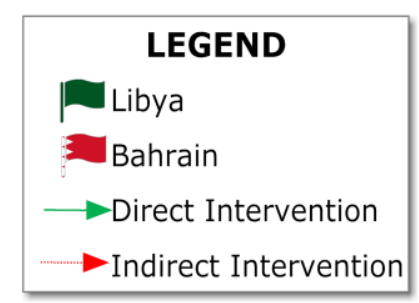

\begin{tabular}{|c|c|}
\hline \multicolumn{2}{|c|}{ Humanitarian Aid in Libya } \\
\hline Slovenia & U.K. \\
\hline \multicolumn{2}{|c|}{ Czech Republic } \\
\hline \multicolumn{2}{|c|}{ Other E.U. Countries } \\
\hline
\end{tabular}

Figure 5.2- Regional and International Military and Humanitarian Contribution in Libya and Bahrain ${ }^{9}$

\footnotetext{
${ }^{9}$ The data in the designed map is retrieved from Task Force (2012) "Can NATO react to the Arab Spring?" The Henry M. Jackson School of International Studies, pp. 1-301
} 


\section{4- The Curse of Sisyphus}

"Where would his torture be, indeed, if at every step the hope of succeeding upheld him? - Albert Camus, Algerian-French Philosopher and Journalist, The Myth of Sisyphus and Other Essays, 1942

Despite the fact that many may argue that the events of 2011 are not yet stories of democratic transition, "more than anything else, the Arab Spring has been about a yearning for democracy" (Pollack et al. 2011: 21). Two years after the occurrence of the uprisings, "enough time has passed to try to make sense of what has happened so far and, perhaps, gain an inkling of where the region is headed" (Pollack et al. 2011: 1). Scholars and practitioners will debate the impact of the Arab Spring for years to come, with old and new questions addressed and revisited.

Sisyphus was condemned to ceaselessly and incessantly rolling a rock to the top of the mountain, which in turn, kept on rolling back due to its own encumbrance a dreadful punishment that is futilely hopeless. However, Sisyphus's fate belongs to him and his rock is but of his own. Comparing the role of external dynamics of democratization in the Middle East to the curse of Sisyphus is a metaphorical symbolization of the Middle Eastern fate. The destiny of the Middle East in the aftermath of the Arab Spring belongs to the people and the Middle Eastern rock is their own. Arabs of course are not immune to democratization and "if the people of the Middle East could have their way, all of the states there would morph into democracies overnight" (Pollack et al. 2011: 87). Therefore, the mere fact that the Arab Spring, an exceptional phenomenon in the Middle East, occurred is a cause of optimism. When studying the MENA, scholars and practitioners should examine it with the lens of possible democratic transitions. Assessing impact of December 2010 
events in a comparative manner on great powers and Middle Eastern countries, Pollack argues:

The impact of the Arab Spring has been particularly profound for the great powers of the world, both the established and the emerging. Because the Middle East has been important for a long time, the established great powers have had interests in the Middle East for similarly long periods, including eras when parts of the Middle East were under their formal or informal control. Consequently, they have vested interests in the region, which are being threatened, reshaped, or even benefitted by the events of the Arab Spring - and often some unknowable combination of the three. What is more, the people of the Middle East, both rulers and ruled, are looking at the great powersespecially to the more established great powers with which they have been dealing with for decades - to help them. And of course, the help that the rulers want is often the diametric opposite of what their people want (Pollack et al. 2011: 277).

What the Middle East has witnessed in terms of "exceptionally rapid, intense, and nearly simultaneous explosion of popular protest [...] united by a shared transnational media and bound by a common identity" (Lynch 2012: 9) contributes to scholarly debates concerning the global and regional impact of the Arab Spring. There will be many threats and impediments in a post-Bouazizi Arab world, and "the first, and most obvious, threat to new Arab democracies is that they will be hijacked by individuals or groups looking to take power, hold on to it, and rule autocratically, all with the help of the veneer of legitimacy conferred by elections" (Pollack et al. 2011: 90). Nevertheless, addressing the importance of external dynamics as a mode of democratic transition can no longer be ignored after the Arab Spring. The Arab Spring demonstrated the role played by external dynamics in authoritarian regime breakdown or maintenance. In the case of Bahrain and Libya, there will be major challenges to address. In a post-Qaddafi era, Libya has to engage in constructive building of state institutions whereas in case of Bahrain, al-Khalifa regime cannot sideline the importance of addressing power-sharing formulas between regime and society. 


\section{Bibliography}

Albrecht, H. \& Schlumberger, O. (2004). Waiting for Godot: Regime change without democratization in the Middle East. International Political Science Association, 25(4), 371-392.

Allison, G.T. \& Beschel, R.P. (1992). Can the United States promote democracy? Political Science Quarterly, 107(1), 81-98.

Almond, G. (1989). Review Article: The national- international connection. British Journal of Political Science, 19, 237-259.

Al- Turk, A. (2011). Libya: from revolt to state-building. In K. Pollack et al (Eds.), The Arab awakening: America and the transformation of the Middle East (pp. 117- 127). U.S.A: The Brookings Institution.

Anderson, L. (1995). Democracy in the Arab world: A critique of the political culture approach. In R. Brynen, B. Korany, \& P. Noble (Eds.), Political liberalization and democratization in the Arab world: Theoretical perspectives (pp. 77-92). Boulder, CO: Lynne Rienner Publishers.

Anderson, L. (2006). Searching where the light shines: Studying democratization in the Middle East. Annual Review of Political Science, 9, 208-209.

Arendt, H. (1958). The origins of totalitarianism ( $2^{\text {nd }}$ ed.). London: Allen \& Unwin.

Ashour, O. (2010, April). De-radicalizing jihadists the Libyan way. Sada, Carnegie Endowment for International Peace. Retrieved from http://carnegieendowment.org/2010/04/07/de-radicalizing-jihadists-libyan$\underline{\text { way/fdv }}$

Barany, Z. (2011, October). The role of the military. Journal of Democracy, 22(4), 28-39.

Bayat, A. (2009). Life as politics: How ordinary people change the Middle East. Stanford: Stanford University Press.

Beblawi, H. (1990). The rentier state in the Arab world. In G. Luciani (Ed.), The Arab State (pp. 85-98). U.S.A: Routledge. 
Beetham, D. (1994). Defining and measuring democracy. London: Sage.

Behr, T. (2012). Lessons learnt: Social unrest in the Arab world: What did we miss? Arts and Humanities Research Council Series, 8, 1-23. Retrieved from http://www.ahrc.ac.uk/What-We-Do/Strengthen-research-impact/Informpublic-policy/Documents/Social_Unrest.pdf

Bellin, E. (2005). Coercive institutions and coercive leaders. In M.P. Posusney, \& M.P. Angrist (Eds.), Authoritarianism in the Middle East: Regimes and resistance (pp. 21-38). Boulder, CO: Lynne Rienner Publishers.

Bellin, E. (2012, January). Reconsidering the robustness of authoritarianism in the Middle East. Comparative Politics, 44(2), 127-149.

Bianco, M. (1975). Gadafi: Voice from the desert. New York: Longman.

Black, I. (2011, March). Concerned neighbors warn against foreign intervention in Libya. The Guardian. Retrieved from http://www.guardian.co.uk/ world/2011/mar/02/neighbours-foreign-intervention-libya

Bradley, J. (2012). After the Arab Spring: How Islamists hijacked the Middle East revolts. U.S.A: Palgrave Macmillan.

Brand, L. (2013). Arab uprisings and mass politics: Possibilities, constraints, and uncertainty. A Joint Wilson Center-USIP Project, The Changing Security Architecture in the Middle East, 3. Retrieved from http://www.wilsoncenter.org/publication/arab-uprisings-and-mass-politicspossibilities-constraints-and-uncertainty

Brynen, R., Moore, P., Salloukh, B., \& Zahar, M.J. (2012). Beyond the Arab Spring: Authoritarianism and democratization in the Arab world. USA: Lynne Rienner Publishers.

Bunce, V. (2000, September). Comparative democratization: Big and bounded generalizations. Comparative Political Studies, 33(6-7), 703- 734.

Bunce, V. (2001, June). Democratization and economic reform. Annual Review of Political Science 4, 43-65. 
Burchill, S., Linklater, A., Devetak, R., Donnelly, J., Nardin, T., Paterson, M., ... True, J. (2009). Theories of international relations.UK: Palgrave Macmillan.

Byman, D. \& Pollack, K. (2011). Regional actors: The changing balance of power in the Middle East. In K. Pollack et al (Eds.), The Arab awakening: America and the transformation of the Middle East (pp.243-249). U.S.A: The Brookings Institution.

Carothers, T. (2007, January). How democracies emerge: The sequencing fallacy. Journal of Democracy, 18(1), 12-27.

Cartalucci, T. (2012, October). NATO's 'Responsibility to Kill': International law suffers another blow in Libya conflict. Global Research, Center for Research on Globalization. Retrieved from http://www.globalresearch.ca/natosresponsibility-to-kill-international-law-suffers-another-blow-in-libyaconflict/5308825

Chorin, E. (2012). Exit the Colonel: The hidden history of the Libyan revolution. U.S.A: PublicAffairs.

Colombo, S. (2012, March). The GCC countries and the Arab Spring: Between outreach, patronage and repression. Instituto Affari Internazionali Working Papers, 12(9), 1-16.

Davies, C. (Ed.). (1992). Global interests in the Arab Gulf. New York: St. Martin's Press.

Davidson, C. (2011). Power and politics in the Persian Gulf monarchies. New York: Columbia University Press.

Diamond, L. (1999). Developing democracy: Toward consolidation. Baltimore: John Hopkins University Press.

Diamond, L., Linz, J., \& Lipset, S. (1989). Democracy in developing countries: Latin America (Vol. 4). Boulder, Co: Lynne Rienner Publishers.

Diamond, L. (2002, April). Elections without democracy: Thinking about hybrid 
regimes. Journal of Democracy, 13(2), 21-35.

Diamond, L. (1992, Summer). Promoting democracy. Foreign Policy, 87, 25-46.

Diamond, L. (2009, July). Why are there no Arab democracies? Journal of Democracy, 21(1), 93-104.

Diwan, K. (2011, March). The dire consequences of Saudi intervention in Bahrain. CNN World. Retrieved from http://globalpublicsquare.blogs.cnn.com/ 2011/03/21/the-dire-consequences-of-the-saudi-intervention-in-bahrain/

Doran, M. \& Shaikh, S. (2011). Bahrain: Island of troubles. In K. Pollack et al (Eds.), The Arab awakening: America and the transformation of the Middle East (pp. 188-197). U.S.A: The Brookings Institution.

Filiu, J.P. (2011). The Arab revolution: Ten lessons from the democratic uprising. Oxford: Oxford University Press.

First, R. (1974). Libya: The elusive revolution. Harmondsworth: Penguin.

Fukuyama, F. (1995). Trust: The social virtues and the creation of prosperity. New York: Simon \& Schuster.

Gause, G. (2011, May). The Middle East academic community and the winter of Arab discontent: Why did we miss it? The Henry L. Stimson Center. Retrieved from http://www.stimson.org/images/uploads/research-pdfs/ Academic Community.pdf

Gause, G. (2000). The persistence of monarchy in the Arabian Peninsula: A comparative analysis. In J. Kostiner (Ed.), Middle East monarchies (pp. 167-186). Boulder, Co: Lynne Rienner Publishers.

Gause, G. (2004). Relations between the Gulf Cooperation Council States and the United States. Dubai, United Arab Emirates: Gulf Research Center.

Gause, G. (2011, July/August). Why Middle East studies missed the Arab spring: The myth of authoritarian stability. Foreign Affairs 90(4), 81-90. 
Gasiorowski, M. (1995, December). Economic crisis and political regime change: An event history analysis. The American Political Science Review, 89(4), 882-897.

Geddes, B. (1999). What do we know about democratization after twenty-five years? Annual Review of Political Science, 2(44), 115-144.

Grand, S. (2011). Democratization 101: Historical lessons for the Arab Spring. In K. Pollack et al. (Eds.), The Arab awakening: America and the transformation of the Middle East (pp. 21-28). U.S.A: The Brookings Institution.

Gray, M. (2011). A theory of later rentierism in the Arab states of the Gulf. (Occasional Paper, Center for International and Regional Studies, Georgetown University School of Foreign Service in Qatar, 7). Retrieved from http://www12.georgetown.edu/sfs/qatar/cirs/ MatthewGrayOccasionalPaper.pdf

Haas, L. (2012, Spring/Summer). Learning from the Arab Spring. The Journal of International Security Affairs, 22, 71-79.

Halliday, F. (2005). The Middle East in international relations: Power, politics, and ideology. Cambridge, U.K: Cambridge University Press.

Halperin, M.H. (1993, Summer). Guaranteeing democracy. Foreign policy, 91, 120-124.

Herb, M. (1999). All in the family: Absolutism, revolution, and democracy in the Middle Eastern monarchies. New York: State University of New York Press.

Herb, M. (2005, April). No representation without taxation? Rents, development, and democracy. Comparative Politics, 37(3), 297-316.

Heydemann, S. (2007, October). Upgrading authoritarianism in the Arab world. The Saban Center for Middle East Policy at the Brookings Institution, Analysis Paper, 13. Retrieved from http://brookings.edu/ /media/ research/files/papers/2007/10/arabworld/10arabworld.Pdf

Howard, P. \& Hussein, M. (2013). Democracy's fourth wave? Digital media and the Arab Spring. Oxford: Oxford University Press. 
Hudson, M. (1988). Democratization and the problem of legitimacy in Middle East politics. Middle East Studies Association Bulletin, 22(2), 22-37.

Hudson, M. (1995). The political culture approach to Arab democratization. In R. Brynen, B. Korany, \& P. Noble (Eds.), Political liberalization and democratization in the Arab world: Theoretical perspectives (pp. 61-76). Boulder, Co: Lynne Rienner Publishers.

Huntington, S. (1991). The third wave of democratization in the late twentieth century. Norman: University of Oklahoma Press.

Huntington, S. (1968). Political order in changing societies. New Haven (CT): Yale University Press.

Ibn Khaldun, W. (1958). The mugaddimah. London: Routledge \& Kegan Paul.

Joyce, M. (2012). Bahrain from the twentieth century to the Arab Spring. U.S.A: Palgrave Macmillan.

Karland, T. \& Schmitter, P. (1991). Modes of transition in Latin America, Southern Europe, and Eastern Europe. International Social Science Journal, 43(2), 269- 284.

Katzman, K. (2013, April). Bahrain: Reform, security, and U.S. policy. Congressional Research Service. Retrieved from http://www.fas.org/ sgp/crs/mideast/95-1013.pdf

Keating, J. (2011, November). Who first used the term Arab Spring? Foreign Policy Blog. Retrieved from http://blog.foreignpolicy.com/posts/2011/11/04/ who_first_used_the term_arab_spring

Khouri, R. (2011). Arab Spring or revolution? The Globe and Mail. Retrieved from http://www.theglobeandmail.com/commentary/arab-spring-orrevolution/article626345/

Kitchen, N. (2012). After the Arab spring: Power shifts in the Middle East? The contradictions of hegemony: The United States and the Arab spring. LSE 
IDEAS Reports. Retrieved from http://eprints.lse.ac.uk/43467/1/After\% 20the $\% 20 \mathrm{Arab} \% 20$ Spring the $\% 20$ contradictions $\% 20$ of $\% 20$ hegemony(lsero). $\underline{\mathrm{Pdf}}$

King, S. (2009). The new authoritarianism in the Middle East and North Africa. Bloomington: Indiana University Press.

Koch, C. (Eds.). (2005). Unfulfilled potential: Exploring the GCC-EU relationship. Dubai, United Arab Emirates: Gulf Research Center.

Kramer, G. (1992, January/February). Liberalization and democratization in the Arab world. Middle East Report, 22, 12-28.

Laham, N. (2007). The American bombing of Libya: A study of the force of miscalculation in Reagan foreign policy. USA: McFarland \& Company, Inc., Publishers.

Lawson, L. (1999). External democracy promotion in Africa: Another false start? Journal of Commonwealth and Comparative Politics, 37(1), 1-30.

Levitsky, S. \& Way, L. (2010). Competitive authoritarianism: Hybrid regimes after the Cold War. Cambridge: Cambridge University Press.

Lindberg, S. (Eds.). (2009). Democratization by elections: A new mode of transition. USA: The John Hopkins University Press.

Linz, J. \& Stepan, A. (1996). Problems of democratic transition and consolidation: Southern Europe, South America, and Post-Communist Europe. Baltimore: John Hopkins University Press.

Lipset, S. M. (1959). Some social requisites of democracy: Economic development and political legitimacy. American Political Science Review, 53, 69- 105.

Luciani, G. (2013, March). Oil, the U.S. and the GCC. Gulf Research Center. Retrieved from http://www.grc.net/index.phpfrm_action=view_newsletter_ web\&sec_code $=$ grcanalysis $\&$ frm_module $=$ contents\&show_web_list_link $=$ $\underline{1 \& \text { int_content_id=80550 }}$ 
Lust, E. (2011, October). Why now? Micro-transitions and the Arab uprisings. [Web log message] The Monkey Cage Blog. Retrieved from http://themonkeycage.org/2011/10/24/why-now-micro-transitions-and-thearab-uprisings/

Lynch, M. (2012). The Arab uprising: The unfinished revolutions of the new Middle East. U.S.A: PublicAffairs.

McCormick, J. (2001, June). Machiavellian democracy: Controlling elites with ferocious populism. American Political Science Review, 95(2), 297-313.

McCoy, J. \& Hartlyn, J. (2009). The relative powerlessness of elections in Latin America. In S. Lindberg (Eds.), Democratization by elections: A new mode of transition (pp. 47-76). U.S.A: The John Hopkins University Press.

McFaul, M. (2005, July). Transitions from post-communism. Journal of Democracy, 16(3), 5-19.

Merlini, C. \& Roy, O. (2012). Arab society in revolt: The West's Mediterranean challenge. U.S.A: The Brookings Institutions.

Milanovic, B. (2011, August). Inequality and its discontents: Why so many feel left behind. Foreign Affairs. Retrieved from http://www.foreignaffairs.com/ articles/68031/branko-milanovic/inequality- and-its-discontents

Mill, J. S. (Ed.). (1973). A system of logic ratiocinative and inductive. In J. M. Robson, Collected works of John Stuart Mill (Vols. 7-8). Toronto: University of Toronto Press.

Moore, P. W. (1994). The international context of liberalization and democratization in the Arab world. Arab Studies Quarterly, 16(3), 43-73.

Moore, P. \& Salloukh, B. (2007, February). Struggles under authoritarianism: Regimes, states, and professional associations in the Arab world. International Journal of Middle East Studies, 39(1), 53-76.

Noueihed, L. \& Warren, A. (2012). The battle for the Arab Spring: Revolution, counter-revolution, and the making of a new era. New Haven: Yale University Press. 
O'Donnell, G. (1993, August). On the state, democratization and some conceptual problems. World Development, 21(8), 1355-1369.

O’Donnell, G., Schmitter, P., \& Whithead, L. (Eds.). (1986). Transitions from authoritarian rule: Comparative perspectives. U.S.A: The John Hopkins University Press.

Otman, W. \& Karlberg, E. (2007). The Libyan economy: Economic diversification and international repositioning. New York: Springer Berlin Heidelberg.

Pargeter, A. (2012). Libya: The rise and fall of Qaddafi. New Haven, U.S.A: Yale University Press.

Peters, J. (2012). The European Union and the Arab Spring: Promoting democracy and human rights in the Middle East. U.K: Lexington Books.

Pollack, K. (2011). Democratizers? The pursuit of pluralism. In K. Pollack, et al. (Eds.), The Arab awakening: America and the transformation of the Middle East (pp. 87- 93). U.S.A: The Brookings Institution.

Pollack, K. (2011). External powers: Riding the Tsunami. In K. Pollack et al. (Eds.), The Arab awakening: America and the transformation of the Middle East (pp. 277- 284). U.S.A: The Brookings Institution.

Pollack, K. (2011). Introduction: Understanding the Arab awakening. In K. Pollack et al. (Eds.), The Arab awakening: America and the transformation of the Middle East (pp. 1-12). U.S.A: The Brookings Institution.

Pollack, K. (2011). Reform: Convincing reluctant regimes to change. In K. Pollack et al. (Eds.), The Arab awakening: America and the transformation of the Middle East (pp. 141- 147). U.S.A: The Brookings Institution.

Pollack, K. (2011). The Arab militaries: The double-edged swords. In K. Pollack et al. (Eds.), The Arab awakening: America and the transformation of the Middle East (pp. 58- 65). U.S.A: The Brookings Institution.

Powell, C. (1996). International aspects of democratization: The case of Spain. In L. Whitehead (Ed.), The international dimensions of democratization: Europe and the Americas (pp. 261-284). Oxford: Oxford University Press. 
Przeworski, A. (1986). Some problems in the study of the transition to democracy. In G. O'Donnell, P. Schmitter, \& L. Whithead (Eds.), Transitions from authoritarian rule: Comparative perspectives (pp. 47- 63). U.S.A: The John Hopkins University Press.

Rustow, D. (1970, April). Transitions to democracy: Toward a dynamic model. Comparative Politics, 2(3), 337-363.

Salame, G. (1994). Democracy without democrats? The renewal of politics in the Muslim world. London: I.B. Tauris.

Salloukh, B. \& Brynen, R. (2004). Persistent permeability? Regionalism, localism, and globalization in the Middle East. Aldershot, U.K: Ashgate.

Sayyid, M. (2007). International dimensions of the Middle Eastern authoritarianism: The G8 and external efforts at political reform. In O. Schlumberger (Ed.), Debating Arab authoritarianism: Dynamics and durability in non-democratic regimes (pp. 215-230). Stanford: Stanford University Press.

Schedler, A. \& Santiso, J. (1988). Democracy and time: An invitation. International Political Science Review, 19(1), 5-18.

Schedler, A. (2009). Sources of competition under electoral authoritarianism. In S. Lindberg (Ed.), Democratization by elections: A new mode of transition (pp. 179-201). U.S.A: The John Hopkins University Press.

Schmitter, P. (1995). On civil society and the consolidation of democracy: Ten propositions. Mimeo: Stanford Department of Political Science.

Schmitter, P. (1996). The influence of the international context upon the choice of national institutions and policies in neo-democracies. In L. Whitehead (Ed.), The international dimensions of democratization: Europe and the Americas (pp. 26-54). Oxford: Oxford University Press.

Schmitter, P. (2010, January). Twenty-five years: Fifteen findings. Journal of Democracy 21(1), 17-28.

Sorensen, G. (1993). Democracy and democratization: Processes and prospects in a changing world. Boulder, Co: Westview Press. 
Stepan, A. \& Linz, J. (2013, April). Democratization theory and the Arab Spring. Journal of Democracy, 24(2), 15-30.

Stepan, A. (1986). Paths toward re-democratization: Theoretical and comparative Considerations. In G. O’Donnell, P. Schmitter, \& L. Whitehead (Eds.), Transitions from authoritarian rule: Comparative perspectives (pp. 64- 84). USA: The John Hopkins University Press.

St. John, R. (2002). Libya and the United States: Two centuries of strife. Philadelphia, U.S.A: University of Pennsylvania Press.

Tovias, A. (1984, April). The international context of democratic transitions. West European Politics, 7(2), 158-171.

Tsingos, B. (1996). Underwriting democracy: The European community and Greece. In L. Whitehead (Ed.), The international dimensions of democratization: Europe and the Americas (pp. 315- 355). Oxford: Oxford University Press.

United Nations Development Programme. (2010). Human Development Report 2010: The real wealth of nations: Pathways to human development. Retrieved from the United Nations Development Programme, Human Development Report website: http://hdr.undp.org/en/reports/global/hdr2010/

United Nations Security Council Resolution 1973. (2011, March 17). Resolution 1973: Adopted by Security Council at its $6,498^{\text {th }}$ meeting. Retrieved from the United Nations Security Council Report website: http://www.securitycouncilreport.org/atf/cf/\%7B65BFCF9B-6D27-4E9C8CD3-CF6E4FF96FF9\%7D/Libya\%20S\%20RES\%201973.pdf

Vira, V. \& Cordesman, A. (2011, June). The Libyan uprising: An uncertain trajectory. Center for Strategic and International Studies. Retrieved from http://csis.org/files/publication/110620_libya.pdf

Way, L. (2011, October.). The lessons of 1989. Journal of Democracy, 22(4), 1727.

Weaver, M. \& Henley, J. (2013, February 14). Bahrain protests second anniversary of uprising. The Guardian. Retrieved from http://www.guardian.co.uk/ world/middle-east-live/2013/feb/14/bahrain- protests-2nd-anniversary-live 
Whitehead, L. (2002). Democratization: Theory and experience. UK: Oxford University Press.

Whitehead, L. (2009, April). Losing the force? The dark side of democratization after Iraq! Democratization, 16(2), 215-242.

Whitehead, L. (Ed.). (1996). The international dimensions of democratization: Europe and the Americas. Oxford: Oxford University Press.

Winkler, D. (2007). Amirs, admirals, and desert sailors: Bahrain, the U.S. Navy, and the Arabian Gulf. Annapolis: Naval Institute Press. 